\title{
Geological and hydrogeological assessment of the Brito Formation: Municipio de Tola, Nicaragua
}

\author{
James K. Adamson ${ }^{1}$ - G. Thomas LaVanchy ${ }^{2} \cdot$ Brandon Stone $^{3}$ - James A. Clark ${ }^{4}$. Stuart J. Dykstra ${ }^{5} \cdot$ Matthew J. Taylor $^{6}$
}

Received: 16 June 2020 / Accepted: 4 May 2021 / Published online: 1 July 2021

(C) The Author(s) 2021

\begin{abstract}
There are sparse hydrogeological data and insufficient hydrogeological knowledge in many areas of the world reliant on groundwater. Nicaragua's Pacific coast is one such region that is also experiencing water scarcity resulting from increasing demand on groundwater resources and climate change. The primary source of water in the region is the aquifer system associated with the Brito Formation, which is a marine sedimentary stratum of mostly sandstone that blankets $75 \mathrm{~km}$ of coastline in southwest Nicaragua. This study focused on the Tola municipality with the objective to advance a conceptual understanding of the hydrogeology and to support sustainable water development. Results demonstrate a heterogeneous aquifer system with regional flow characteristics and other factors that influence groundwater availability and water quality. Primary porosity is low, and secondary porosity is the primary mechanism of aquifer storage and is influenced by geological structure and diagenesis processes. Groundwater recharge is spatially and temporally heterogeneous and direct recharge is low. Infiltration of streamflow and runoff, especially early in the rainy season, is thought to be a large component of groundwater recharge. Climate, flow and recharge dynamics, and low storage capacity make the Brito Formation a sensitive resource and vulnerable to drought, increased abstraction, and climate change. This assessment provides data and insights useful for informing future studies and investments within the region and may be applicable in other Central American and Caribbean nations with coastal sandstone aquifers.
\end{abstract}

Keywords Groundwater management $\cdot$ Coastal aquifers $\cdot$ Developing countries $\cdot$ Nicaragua

\section{Introduction}

Groundwater resources in the Pacific Coastal Plain and Pacific Hills of SW Nicaragua are scarce and critical due to the climate, lengthy annual dry season, mountainous topography, and lack of perennial surface water. Drilling and abstraction of groundwater by local communities and the tourism sector

James K. Adamson

james@northwaterco.com

G. Thomas LaVanchy

thomas.lavanchy@okstate.edu

Brandon Stone

brandon@hydrologica.com

James A. Clark

james.a.clark@wheaton.edu

Stuart J. Dykstra

dykstra.stuart@gmail.com

Matthew J. Taylor

matthew.taylor@du.edu continues to increase, exposing regional water challenges such as dry wells or saltwater intrusion, which have adversely impacted most stakeholders (LaVanchy 2017). The 2014-2016 drought produced three of the driest years since 1968 and exposed the severity of the issue and lack of water security in the region. Impacts of the drought were particularly acute in the Tola municipality, an area of particular tourism value,

1 Northwater International, Chapel Hill, NC 27514, USA

2 Department of Geography, Oklahoma State University, Stillwater, OK 74078, USA

3 HydroLOGICA, S.A., Managua, Nicaragua

4 Department of Geology, Wheaton College, Wheaton, IL 60187, USA

5 Calvin University Clean Water Institute, Grand Rapids, MI 49546, USA

6 Department of Geography \& the Environment, University of Denver, Denver, CO 80208, USA 
which is both endorsed and subsidized by the national government to bolster the national economy (LaVanchy et al. 2017). Tourism has been shown to use disproportionate amounts of water relative to local populations (Becken 2014; Tortella and Tirado 2011), thus identification of sufficient and sustainable quantities of groundwater in this region is necessary to (1) support the economic viability of tourism, (2) ensure equity of water access for residents, and (3) inform the over-arching water management aims of the national government.

Groundwater use in Tola has traditionally been limited to boreholes equipped with rope pumps, hand pumps, and small submersible pumps to serve community, residential, and small commercial demands. Many rural and dispersed populations rely on shallow hand-dug wells where water tables are shallow. Between 2012 and 2018, tourism development surged, fueled by world-renowned surfing, infrastructure improvements, a sustained period of political stability, and lower investment costs compared to neighboring Costa Rica (LaVanchy et al. 2020). Over this period, reliance on and usage of groundwater increased significantly across the municipality.

Despite the importance of groundwater and recent droughtrelated challenges, there remains a lack of data and knowledge, and conceptual hydrogeological models have not been advanced for the important aquifer systems. Most of the available scientific literature on the subsurface of SW Nicaragua is derived from mining and petroleum-related exploration during the last century, as well as interoceanic canal planning dating back to the nineteenth century. Limited hydrogeological studies have been made on Pacific littoral areas of Nicaragua. Calderón Palma and Bentley (2007), Corriols et al. (2009), and Moncrieff et al. (2007) provided conceptual and flow system insights on the Leon-Chinandega aquifer (further north and in different geological units than Tola), and Calderón and Uhlenbrook (2016) characterized the climate water balance dynamics for a coastal catchment to the south of Tola.

This paper focuses on the Brito Formation (Brito Fm) sedimentary strata of Eocene and late Paleocene age that blanket a majority of the Pacific Coastal Plain and Pacific Hills in SW Nicaragua. The Brito Fm exceeds 2,500 $\mathrm{m}$ in thickness and hosts important discontinuous aquifer systems of the region. Although the geology has been well studied (Kumpulainen 1995; Levi et al. 1995; McBirney and Williams 1965; Parsons Corporation 1972), hydrological research and regional context data are limited. Studies by Parsons Corporation (1972) and Krásný and Hecht (1998) provided baseline mapping in the region; however, the supporting datasets are unavailable and the resolution is limiting. Webster et al. (2001) described the overall state of water resources in Nicaragua as abundant, but also noted the groundwater potential of the Brito Fm is lacking, with unsuitable to small quantities of groundwater available. The absence of data, studies, and associated conceptual model development creates significant challenges and cost barriers to planning and informed decision-making related to sustainable use of the aquifers. This paper attempts to synthesize an array of desktop research, data collection, and observations from several initiatives and field missions led by the authors between 2012 and 2016. Many of the data collection efforts were isolated from one another, supporting small research projects and specific stakeholders or clients. The resulting cumulative base of data and knowledge were considered a valuable resource for researchers, practitioners, and the government, thus the authors aligned to produce a single peer-reviewed paper. The objectives are to (1) present datasets, (2) bring awareness to the groundwater resources of the region, (3) advance a conceptual hydrogeological model, and (4) provide a technical basis to help guide groundwater planning, development, management, and continuing research.

\section{Study area and setting}

\section{Physical setting}

The Brito Fm outcrops along the Pacific coast of SW Nicaragua and NW Costa Rica. Within Nicaragua, outcrops encompass approximately $1,284 \mathrm{~km}^{2}$ along the coast and extend inland to the Pacific Hills as far as $25 \mathrm{~km}$ (Fig. 1). The outcrop area in Nicaragua includes approximately $60 \%$ of the Rivas, $40 \%$ of the Carazo, and a small portion of the Granada administrative departments. The municipality of Tola is the focus area of this study as a large portion of it is underlain by the Brito Fm (Fig. 1).

The Brito Fm consists of marine-origin deep and shallow water sandstones, siltstones, and claystones of Paleogene age with a thickness estimated in excess of 2,500 m (Parsons Corporation 1972). Black shales and silicified limestones have also been documented within the formation (Astorga 1988; Astorga 1987; Darce et al. 2000). Depositionally, the Brito Fm is interpreted to represent stacked channel-levee deposits of small-scale radial, overlapping submarine fans (Struss et al. 2007; Winsemann and Seyfried 1991). The rock is predominately volcanogenic, has a high content of quartz and plagioclase feldspar, and has experienced a wide range of diagenesis from early to late stage. The Las Sierras group and Masachapa Formation unconformably overlie the Brito Fm in some areas north of Tola (Hoffstetter et al. 1960). In Tola, Quaternary sediments are the only geological units that overlie the Brito Fm across an extent of approximately $162 \mathrm{~km}^{2}$, much of which is associated with three drainages and a coastal plain. Underlying the Brito Fm is the Rivas Fm of Cretaceous age, as well as Tertiary intrusions of diorite/andesite (Fig. 1).

Topography and geomorphology result from tectonic processes associated with subduction of the Cocos Plate beneath 

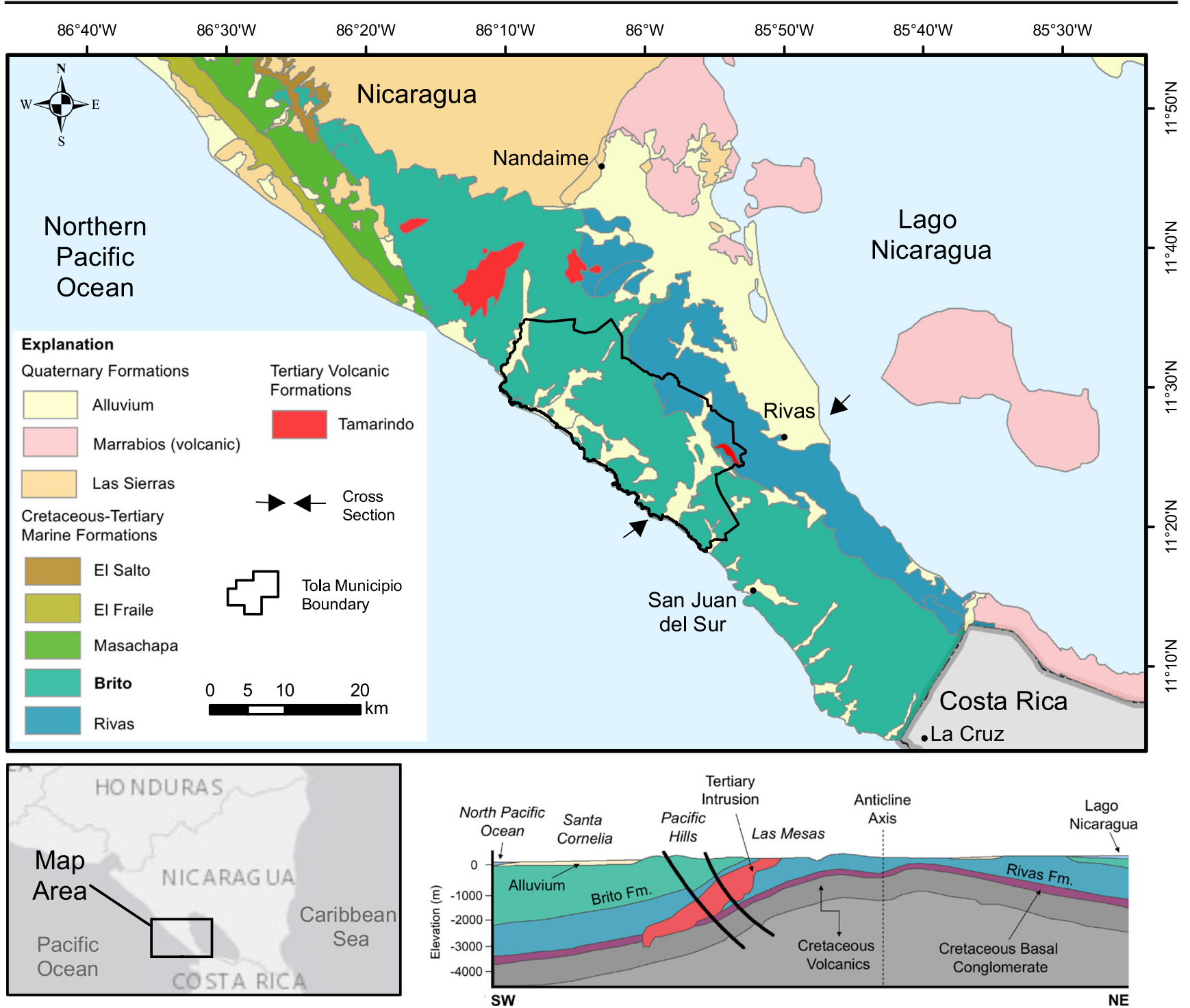

Fig. 1 Geological map and geological cross section of the study area illustrating the extent and setting of the Brito Formation (geology and section modified from Bracci and Gludace 1958; INE 2002; INETER 1988; and Parsons Corporation 1972)

the Caribbean Plate at the Middle American Trench. The uplift of marine sedimentary rocks is greatest inland to the northeast where elevations reach approximately $360 \mathrm{~m}$ above sea level (masl). Broad coastward sloping uplands and hills are dissected by steep structurally controlled drainages that flow southwest towards the coastal plain.

Drainage and hydrology are characterized by short and linear ephemeral river systems, which are structurally controlled by geological features. The largest watershed and river systems include the Brito River $\left(40 \mathrm{~km}^{2}\right)$, Escalante River $\left(20 \mathrm{~km}^{2}\right)$, and Nagualapa River $\left(45.5 \mathrm{~km}^{2}\right)$. These watersheds originate in the Pacific Hills, the channels exhibit low sinuosity and drain westerly towards the Pacific Ocean. Most of these streams and rivers are dry for large portions of the year, thereby making groundwater the primary source of available water.
Southwest Nicaragua is part of the Central American Dry Corridor (CADC) and is characterized as winter dry equatorial (Aw) within Köppen-Geiger climate types. The tropical dry forest experiences unevenly distributed rainfall and distinct wet and dry seasons (Fig. 2). According to QuesadaHernández et al. (2019), the CADC has a drier climate than other areas of Central America and is prone to drought due to a variety of interacting climatic drivers (El Niño Southern Oscillation (ENSO), the Caribbean Low-Level Jet, and the Inter-tropical Convergence Zone). Mean annual temperatures across Tola range from 23.8 to $26.1{ }^{\circ} \mathrm{C}$, with minimum and maximum temperatures of 17.6 and $35.5^{\circ} \mathrm{C}$, respectively. Mean annual precipitation is spatially variable, ranging from 1,292 to $1,618 \mathrm{~mm} /$ year (Fick and Hijmans 2017). Nearly all of the annual rainfall occurs from May to October, with the canicula (brief summer drought) breaking the rainy season in 


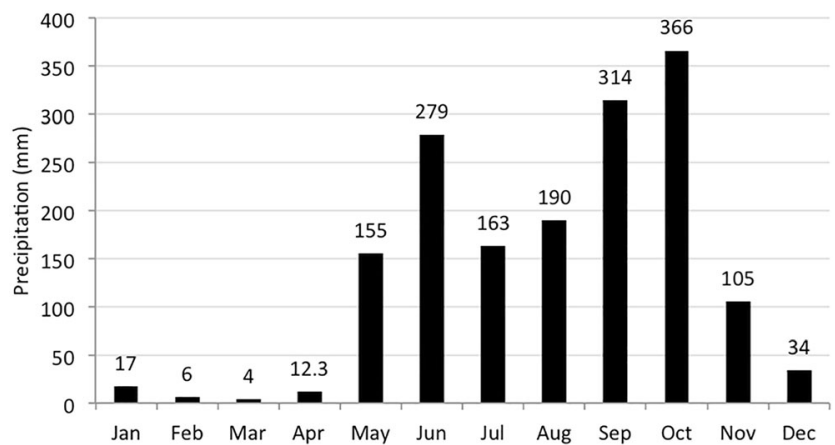

Fig. 2 Average monthly precipitation distribution in the Tola municipality for the period 1970-2000 (derived from WorldClim2, Fick and Hijmans 2017)

July and August. During the 2015 drought, annual rainfall amounted to only 517 and $569 \mathrm{~mm}$ at the Limon and Rivas meteorological stations, respectively (INETER 2016). During 2014-2016, the study area experienced three of the five driest year dating back to 1968 (INETER 2016).

The study area is greatly affected by ENSO climate events (Quesada-Hernández et al. 2019). The monitoring period of this research captured the El Niño event of 2015-2016, which classified as very strong on the Oceanic Niño Index. During the past 40 years, three referenced El Niño events have occurred with "very strong" amplitude. The HadGEM2-ES (RCP4.5 scenario) global circulation model indicates the study area could experience as much as a $3 \%$ decrease in precipitation by 2050 , and mean temperature increases up to $2.4^{\circ} \mathrm{C}$ (Collins et al. 2011). Imbach et al. (2018) found similar trends in their downscaled simulations (8-km resolution) from the HadGEM2-ES (RCP4.5 scenario). These predicted climate change dimensions will negatively affect the availability of water resources across the study area.

\section{Hydrogeological insights from well records}

The Brito Fm is considered the primary geological formation that supports aquifer systems throughout Tola. The sedimentary rocks of the Rivas Fm also support groundwater usage in the NE portion of Tola where the Brito Fm is absent. Groundwater is also locally available in unconsolidated alluvium and colluvium.

Based on water point surveys, hand dug wells are located throughout the municipality and have depths up to $32 \mathrm{~m}$, which exceeds the $25 \mathrm{~m}$ often considered the maximum feasible depth of excavation for a hand dug well (Abbott 2013). Most of the wells produce water from fractured rock beneath unconsolidated strata, while some collect water from alluvium and colluvium. In the higher elevations of the Pacific Hills, many rural families rely on shallow perched groundwater found by digging in ravines and drainages.
Drilled wells serve some rural communities, private residences, schools, churches, businesses, and resort developments. The town of Virgen Morena and several agricultural producers also have drilled wells. The town of Tola has municipal wells completed in the Rivas Formation. Data available for drilled wells are scarce; however, a limited set of records $(n=41)$ were reviewed and are summarized in Table 1. Lithological logs indicate variable thickness of topsoil, weathered sandstone, and unconsolidated deposits up to $15 \mathrm{~m}$ in thickness. Some logs described clay or shale overlying the bedrock up to $14 \mathrm{~m}$ thick; these are typically closer to the coast. The Brito Fm is generally described in driller logs as fractured rock, hard consolidated rock, or semiconsolidated rock. Some more detailed records documented layered stratigraphy of fractured sandstones of variable hardness, clay and silt, and intercalations of volcanogenic pyroclastic rock. A few logs reported intercalations of basalt, however, basalt was not observed during field reconnaissance and is not documented in the research literature. These hard, consolidated rock layers are interpreted as graywackes and are locally referred to as 'bluestone' or cascayo duro.

Drilled well depths ranged from 30.5 to $260 \mathrm{~m}$ and produced a high range of airlift yields between 1.1 and $56.8 \mathrm{~m}^{3} / \mathrm{h}$ (0.3-15.7 L/s; Table 1). Twenty-four wells had pump test data with specific capacity ranging from 0.2 to $77.4 \mathrm{~m}^{3} / \mathrm{h}-\mathrm{m}$, with an average of 1.9 (Table 1). Hydraulic conductivity and storage values from drilling reports fall within a large range that are consistent with literature values for unfissured sandstone, fractured sandstone, and semiconsolidated sandstone (Bouwer 1978; Domenico and Schwartz 1990; Heath 1983). The only known wells in the region drilled deeper than $260 \mathrm{~m}$ are petroleum exploration wells, some of which are nearly 4,000 m deep and penetrate the full thickness of the Brito Fm (Ranero et al. 2000; Struss et al. 2008).

The depth to the uppermost fracture and production zones is in the range of 5-40 m, and many boreholes drilled deeper continue to intersect water yielding fractures. As an example,

Table 1 Summary statistics from drilled wells in Tola municipality, 24 of which had pump test data and 12 with aquifer analysis

\begin{tabular}{llll}
\hline Summary statistics & $n$ & Range & Mean \\
\hline Well depth $(\mathrm{m})$ & 41 & $30.5-260$ & 71.6 \\
Airlift yield $\left(\mathrm{m}^{3} / \mathrm{h}\right)$ & 41 & $1.1-56.8$ & 6.8 \\
Pump test rate $\left(\mathrm{m}^{3} / \mathrm{h}\right)$ & 24 & $1.2-40.9$ & 8.3 \\
Static water level $(\mathrm{m}$ bgs) & 24 & $0.8-53.3$ & 9.0 \\
Drawdown $(\mathrm{m})$ & 24 & $0.2-27.6$ & 6.4 \\
Specific capacity $\left(\mathrm{m}^{3} / \mathrm{h}-\mathrm{m}\right)$ & 24 & $0.2-77.4$ & 1.9 \\
Hydraulic conductivity $(\mathrm{m} /$ day) & 12 & $0.05-90$ & 1.3 \\
Storativity & 12 & $0.003-0.100$ & 0.008 \\
\hline
\end{tabular}

Note: Four of 41 wells were reported to produce brackish water 
a drilling $\log$ from a resort development reported $2 \mathrm{~L} / \mathrm{s}$ at the bedrock interface $(20 \mathrm{~m})$, diffuse production of $9.5 \mathrm{~L} / \mathrm{s}$ from 20 to $88 \mathrm{~m}$, and an additional $4.5-7.5 \mathrm{~L} / \mathrm{s}$ at $88 \mathrm{~m}$. One of the municipal production wells at Virgen Morena produces over $6 \mathrm{~L} / \mathrm{s}$ from two fracture zones (15-32 $\mathrm{m}$ and 50-60 m) which are separated by hard consolidated rock (ENACAL 2006).

The Brito Fm has upper and lower hydrostratigraphic differentiation. The upper section is typically fractured and weathered rock beneath a veneer of unconsolidated sediments and supports most of the hand dug wells throughout Tola. In contrast, the lower section is more compacted with fracture zones and semiconsolidated strata that are typically confined or semiconfined. Some drilled wells located closer to the coast in alluvial areas produce water from both the alluvium and underlying bedrock aquifer.

\section{Methods}

Fieldwork and data collection were focused in Tola between 2012 and 2016 (Fig. 3), which included the 2015-2016 El Niño event. Well owners and drillers generously allowed the authors to review private well records and data. Due to confidentiality requested by several contributors, coordinates of wells are not published. Climate data include monthly precipitation and evapotranspiration (ET) from the Integrated MultiSatellite Retrievals for GPM (Huffman et al. 2019). Daily precipitation data were made available from a privately operated meteorological station near El Limon Dos. The WorldClim2 dataset was applied to generate average annual precipitation values across Tola (Fick and Hijmans 2017).

The March-April 2014 reconnaissance included geology and hydrogeology transects, with geological observations and measurements at 51 stations (Fig. 3). Rock samples from 10 outcrops were submitted for mineral assay and porosity analysis at the Colorado School of Mines laboratory using Quantitative Evaluation of Materials by Scanning Electron Microscopy (QEMSCAN).

A water point survey included in-situ measurements of electrical conductivity (EC), temperature, and $\mathrm{pH}$ collected from wells $(n=32)$ and springs $(n=2)$ using an Oakton PCSTestr 35 multiparameter tester. When possible, well depth and static water levels were measured using a water level meter. A subset of wells $(n=12)$ were analyzed for $E$. coli

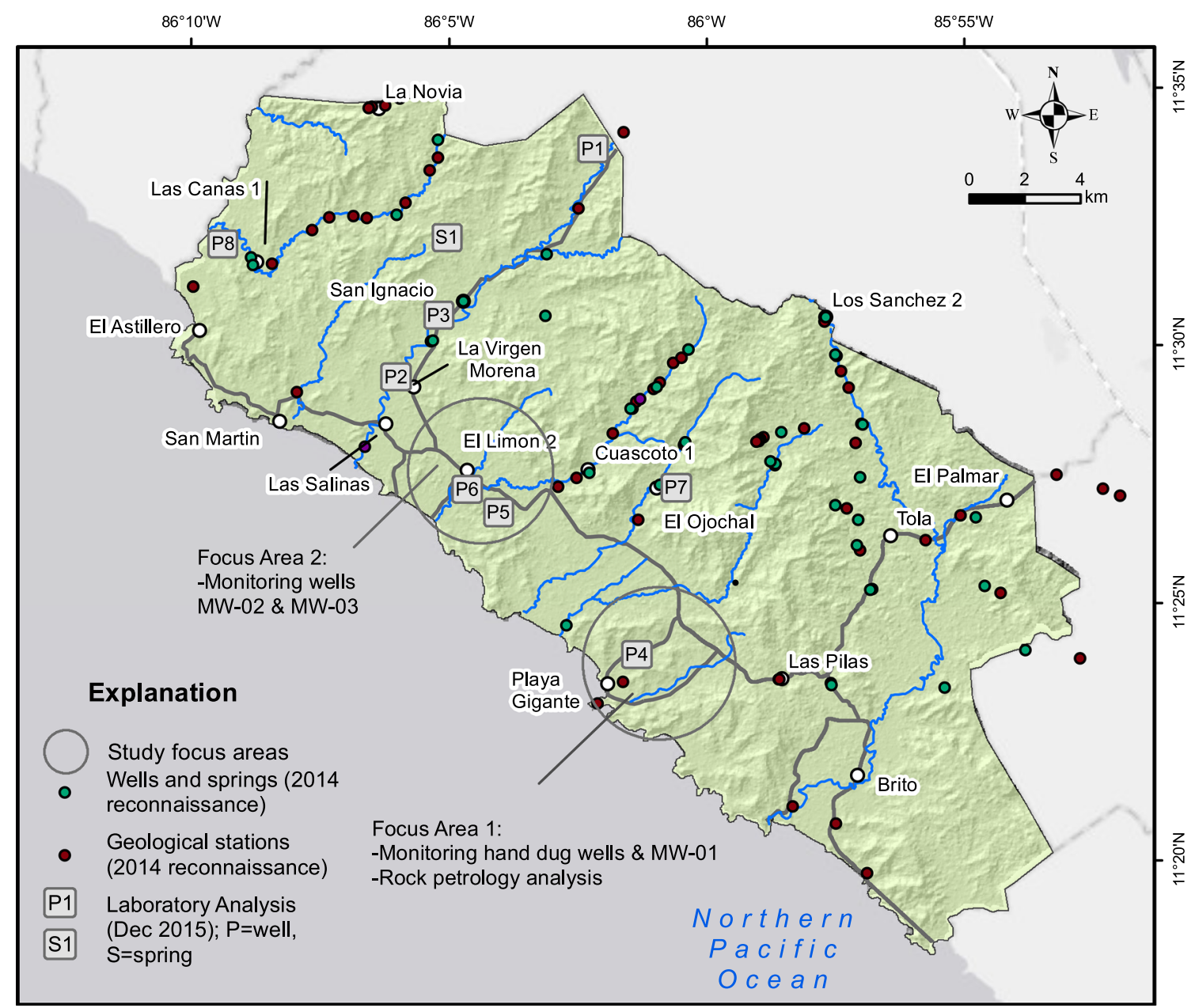

Fig. 3 Map of data collection locations within the municipality of Tola, Nicaragua 
bacteria, $\mathrm{NO}_{3}-\mathrm{N}, \mathrm{NO}_{2}-\mathrm{N}$, turbidity, and hardness by the Universidad Nacional Autónoma de Nicaragua (UNAN). An additional subset of six drilled wells, two hand dug wells, and one spring were sampled in December 2015 and analyzed for stable isotopes and hydrochemistry at Isotech Laboratories and First Environmental Laboratories (Illinois, USA). Charge balance error analysis for ions was less than $10 \%$ for all samples and calculated according to Freeze and Cherry (1979). Using these laboratory results, TDS and EC relationship was applied to samples where TDS results were not available. This was achieved by multiplying the EC value $(\mu \mathrm{S} / \mathrm{cm})$ by a regionally calibrated value of 0.64 to derive TDS in $\mathrm{mg}$ / L.

General piezometric mapping for Tola was performed with kriging and manual methods supported by Surfer and ArcGIS software. The piezometric analysis incorporated static water elevations measured between 2014 and 2020 from 25 drilled wells and 18 hand dug wells. Data were also derived from various dates documented in drilling reports to strengthen spatial coverage. Hand dug well measurements were not strongly weighted in the statistical and manual interpolation methods, especially if they were interpreted to be shallower perched groundwater.

A well inventory in 2012 documented 76 hand dug wells in the Playa Gigante area, and a monitoring program was initiated to document water levels during the dry season and rainy season over several years. The wells ranged in depth from 2.5 to $18.7 \mathrm{~m}$ and water levels were monitored bi-annually between 2012 and 2016, capturing five dry and rainy season sequences. Volunteer citizen scientist approaches were applied to support the data acquisition in the manner of Connors et al. (2012) (Fig. 4). Analysis was performed on water depth variability and dry well occurrences to illustrate the problem and its socio-economic significance. Water-table elevation mapping and analysis was performed for two snapshot events (December 2013 and November 2015) using Surfer software to analyze and illustrate the impacts of the 2015 drought.

Three private production wells were monitored for water level and specific conductance (SC) using Schlumberger CTD-DIVER data loggers. MW-01 is $7 \mathrm{~km} \mathrm{NW}$ of Playa Gigante and was monitored from March 2014 through June 2017. MW-02 and MW-03 in the El Limon Dos area were monitored in 2016. Atmospheric correction was applied from barometric data loggers deployed nearby to monitoring sites. The three wells were completed in the Brito Fm and had total depths between 34 and $76 \mathrm{~m}$ and pumping rates ranging from 4 to $8.9 \mathrm{~L} / \mathrm{s}$ (Table 2).

Rainfall samples $(n=17)$ were collected between March 2014 and September 2016 and analyzed for low-level chloride. Samples were collected directly or from roof downspouts after allowing for a first flush. Most rain samples were captured in Playa Gigante, within $1 \mathrm{~km}$ of the coast at an elevation of 17 masl. Other samples were captured near El Limon Dos, approximately $250 \mathrm{~m}$ from the coast at an elevation of 12 masl. Samples were refrigerated prior to laboratory analysis.

\section{Results}

\section{Groundwater flow}

Static water level data generated from reconnaissance efforts were used to support the creation of a piezometric map (Fig. 5). The mapping is conceptual in nature due to limits in spatial coverage and temporal variability of water level data and does not present a 'snapshot' in time, nor is it representative of drought conditions.

The regional SW orientation of groundwater flow is fairly uniform with steeper hydraulic gradients in the hills and flow diverging towards the coastal plains and larger valleys where the gradients decrease. A groundwater divide transects N-S from Los Sanchez to the coast parallel with the Brito River, and another groundwater divide may be present in the NW near the community of Astillero. In the NE of Tola, the Brito Fm and underlying Rivas Fm may be interconnected hydrogeologically. The Brito River may also have relevant hydrogeological influences on the Brito and Rivas Fm groundwater farther upstream and west of Tola.

The piezometric surface is below most of the river beds in Tola, except for the lower sections of the Brito and Nagualapa

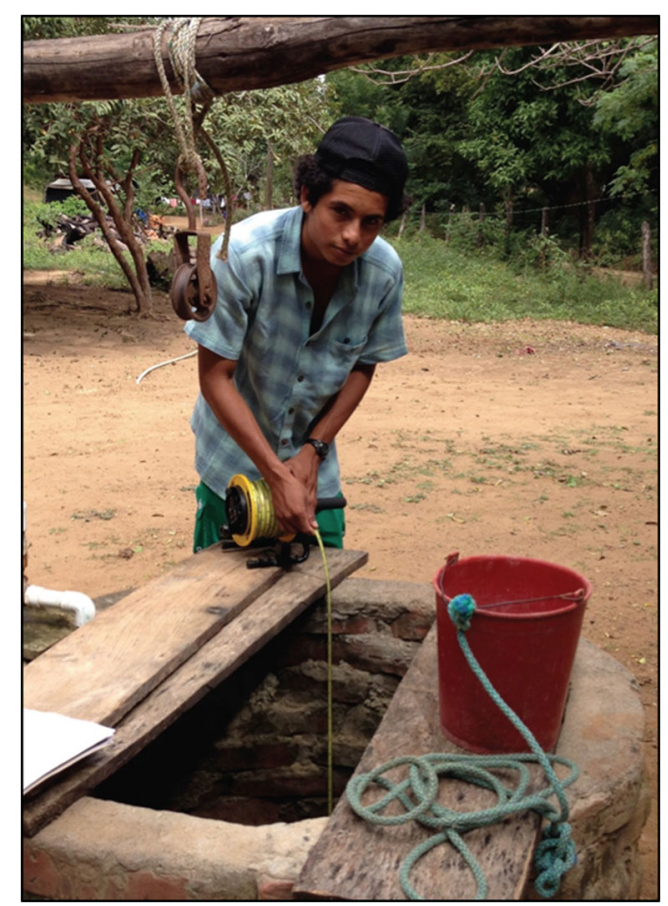

Fig. 4 Volunteer citizen science data collection at one of the hand dug wells in Tola 


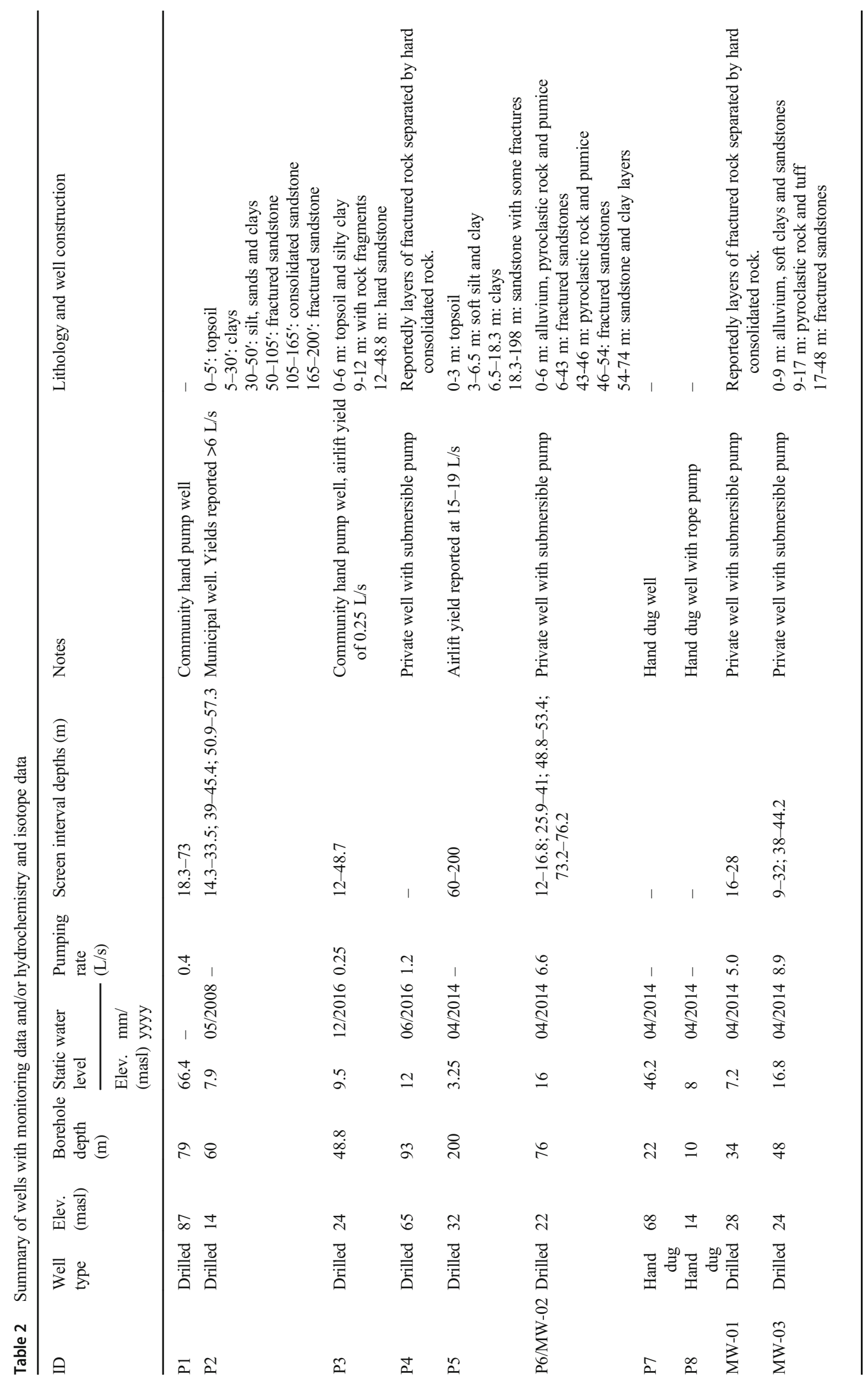




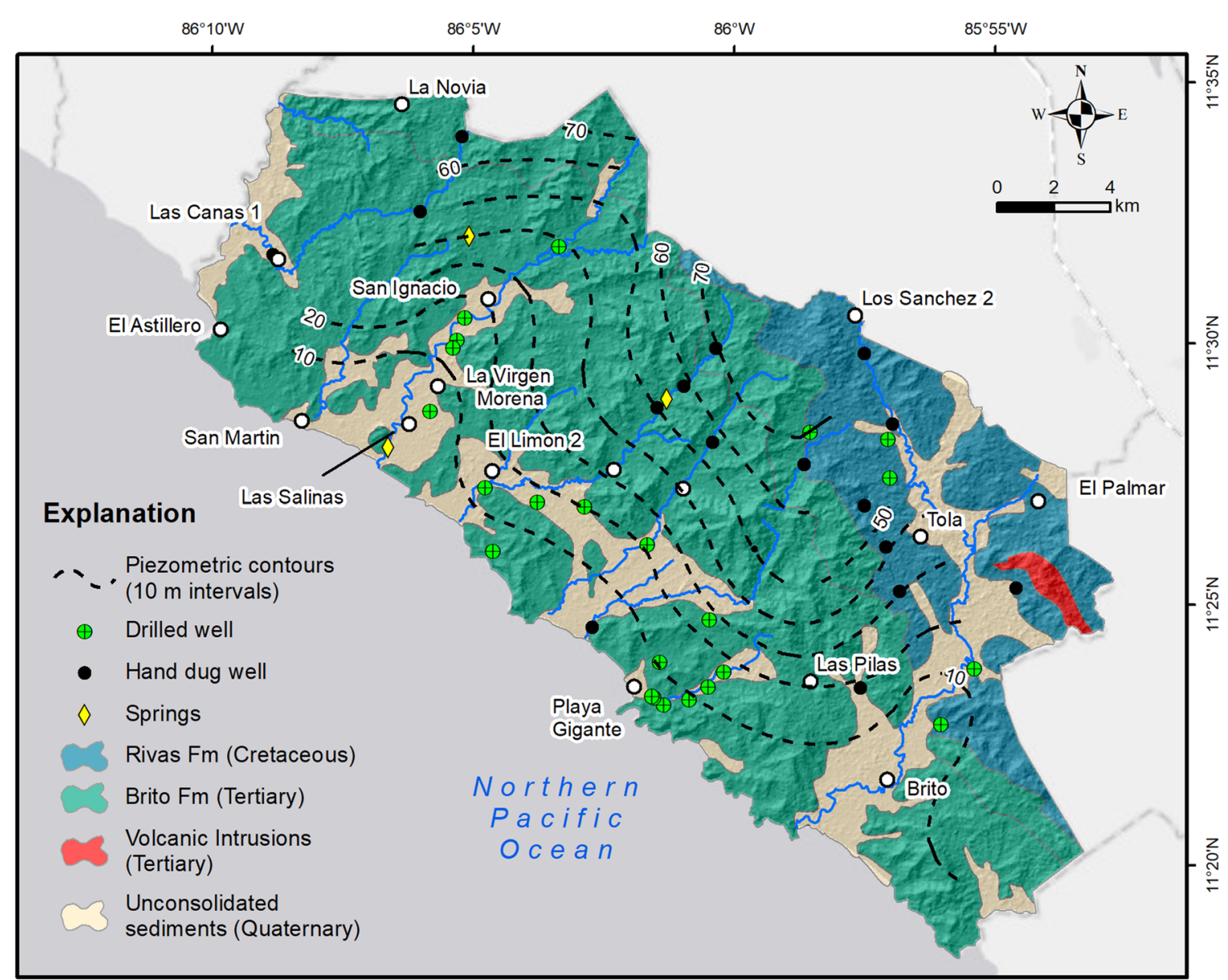

Fig. 5 Regional groundwater flow of the Brito Formation aquifer system in the Tola municipality

rivers. The drainages extending into the hills between Playa Gigante and El Limon Dos are situated well above the piezometric surface and may be a source of recharge when they are flowing. The coastal plain near El Limon Dos has a large contributing area of groundwater flow. Coincidentally, this area has some of the most productive wells in the region. The area between Playa Gigante and the Brito River has a limited contributing area of groundwater flow compared to the rest of the municipality.

\section{Water quality and hydrochemistry}

Over 30 wells were inventoried throughout Tola in March and April of 2014. Table 3 includes summary statistics of data collected. A subset of 12 wells was selected for supplemental water quality analysis and these are presented in Table 4. Only three freshwater springs were found in Tola, all of which were flowing less than $0.25 \mathrm{~L} / \mathrm{s}$ in March-April 2014 and were used as water supplies for nearby residents. The water quality of the springs was similar, with temperature range $26.8-27.9^{\circ} \mathrm{C}$, EC 600-621 $\mu \mathrm{S} / \mathrm{cm}$, and $\mathrm{pH} 7.0-7.6$.

Based on the 2014 dataset, EC had a wide range but did not exceed World Health Organization (WHO) drinking water guidelines of $1,500 \mu \mathrm{S} / \mathrm{cm}$ (WHO 2017) at any locations. Temperature of groundwater was as high as $35.2{ }^{\circ} \mathrm{C}$, correlating to geothermal areas. None of the wells exceeded WHO guidelines for nitrate $\left(10 \mathrm{mg} / \mathrm{L} \mathrm{NO}_{3}\right.$ as $\left.\mathrm{N}\right)$, however, 11 of 12 tested positive for coliform bacteria. Two of the wells had turbidity greater than the WHO guideline of 5 NTU (WHO 2017). All 12 wells had water that was considered hard to very hard, based on analysis performed by UNAN.

Table 3 Water quality summary of wells from March-April 2014 reconnaissance

\begin{tabular}{lllll}
\hline Summary statistics & $n$ & Range & SD & Mean \\
\hline Temperature $(\mathrm{C})$ & 31 & $26.5-35.2$ & 1.46 & 28.3 \\
Conductivity $(\mu \mathrm{S} / \mathrm{cm})$ & 31 & $391-1,128$ & 156 & 656 \\
$\mathrm{pH}$ & 31 & $6.5-8.1$ & 0.34 & 7.3 \\
$\mathrm{Hardness}(\mathrm{mg} / \mathrm{L})$ & 31 & $180-330$ & 37.8 & 235 \\
$\mathrm{NO}_{3}-\mathrm{N}(\mathrm{mg} / \mathrm{L})$ & 12 & $0-6.3$ & 2.23 & 2.2 \\
$\mathrm{NO}_{2}-\mathrm{N}(\mathrm{mg} / \mathrm{L})$ & 12 & $0-0.01$ & 0.003 & 0.003 \\
Turbidity $(\mathrm{NTU})$ & 12 & $0.5-73.2$ & 20.69 & 8.1 \\
Static water level (m bgs) & 20 & $3.5-30.5$ & 7.3 & 9.5 \\
\hline
\end{tabular}


Table 4 Water quality results from a subset of 12 wells sampled between 11 and 20 March 2014

\begin{tabular}{|c|c|c|c|c|c|c|c|c|c|c|}
\hline Sample ID & $\begin{array}{l}\text { Latitude } \\
\text { (dd) }\end{array}$ & $\begin{array}{l}\text { Longitude } \\
\text { (dd) }\end{array}$ & $\begin{array}{l}\text { Temp }{ }^{\mathrm{a}} \\
{ }^{\circ} \mathrm{C}\end{array}$ & $\begin{array}{l}\text { Turbidity } \\
\text { (NTU) }\end{array}$ & $\mathrm{pH}^{\mathrm{a}}$ & Conductivity $^{\mathrm{a}}(\mu \mathrm{S} / \mathrm{cm})$ & $\begin{array}{l}\text { Hardness } \\
(\mathrm{mg} / \mathrm{L})\end{array}$ & $\begin{array}{l}\mathrm{NO}_{3^{-}} \\
\mathrm{N}^{\mathrm{b}} \\
(\mathrm{mg} / \mathrm{L})\end{array}$ & $\begin{array}{l}\mathrm{NO}_{2^{-}} \\
\mathrm{N}^{\mathrm{b}} \\
(\mathrm{mg} / \mathrm{L})\end{array}$ & Total coliform $^{\mathrm{a}}$ \\
\hline AN-255 & 11.4584 & -86.0380 & 27.7 & 0.90 & 7.09 & 642 & 288 & 0.81 & 0.00 & $P$ \\
\hline AN-256 & 11.4621 & -85.9793 & 27.5 & 0.80 & 7.20 & 607 & 300 & 0.85 & 0.01 & $\mathrm{P}$ \\
\hline AN-257 & 11.5089 & -85.9613 & 28.3 & 0.50 & 7.43 & 670 & 272 & 2.38 & 0.00 & $\mathrm{P}$ \\
\hline AN-259 & 11.4433 & -85.9508 & 27.8 & 10.70 & 7.09 & 391 & 180 & 4.70 & 0.00 & $\mathrm{P}$ \\
\hline AN-260 & 11.4442 & -85.9128 & 28.2 & 1.00 & 7.66 & 590 & 264 & 6.34 & 0.00 & $\mathrm{P}$ \\
\hline AN-237 & 11.5293 & -86.0517 & 29.0 & 73.20 & 8.06 & 678 & 274 & 0.00 & 0.00 & $P$ \\
\hline AN-238 & 11.5093 & -86.0520 & 28.5 & 2.40 & 7.32 & 580 & 235 & 3.13 & 0.00 & A \\
\hline AN-239 & 11.5141 & -86.0785 & 29.7 & 1.00 & 7.46 & 720 & 278 & 0.05 & 0.00 & $\mathrm{P}$ \\
\hline AN-240 & 11.5257 & -86.1467 & - & 0.80 & 7.53 & 816 & 267 & 0.14 & 0.00 & $\mathrm{P}$ \\
\hline AN-274 & 11.3890 & -85.9229 & 28.4 & 2.90 & 7.22 & 880 & 330 & 1.08 & 0.00 & $P$ \\
\hline AN-275 & 11.4571 & -85.9503 & 27.9 & 2.00 & 7.52 & 558 & 251 & 5.52 & 0.01 & $\mathrm{P}$ \\
\hline AN-276 & 11.4545 & -86.0150 & 27.6 & 0.90 & 7.21 & 660 & 301 & 1.33 & 0.00 & $\mathrm{P}$ \\
\hline
\end{tabular}

${ }^{\text {a }}$ Measured in the field

${ }^{\mathrm{b}}$ Laboratory analysis

Notes: Total coliform analyzed with HACH PathoScreen methods: $P$ present, $A$ absent

Figures 6 and 7 illustrate the hydrochemistry and water quality of groundwater in Tola (Table 5) based on sampling in December 2015. Three primary hydrochemical facies are differentiated. The $\mathrm{Ca}-\mathrm{SO}_{4}$ sulfate group (wells P3, P6, P8, and $\mathrm{P} 2$ ) is generally inland and has increased dissolved solids.
Well P8 may have seawater or geothermal influence as sodium chloride is elevated. The $\mathrm{Ca}-\mathrm{HCO}_{3}$ group (wells $\mathrm{P} 1, \mathrm{P} 7$, $\mathrm{S} 1$, and $\mathrm{P} 2$ ) is typically more distal from the coast, closer to surface water, and exhibits the lowest concentration of dissolved solids. Well P2 falls in the transition zone between
Fig. 6 Piper plot of groundwater samples from the Brito Formation (Tola municipality, Nicaragua)
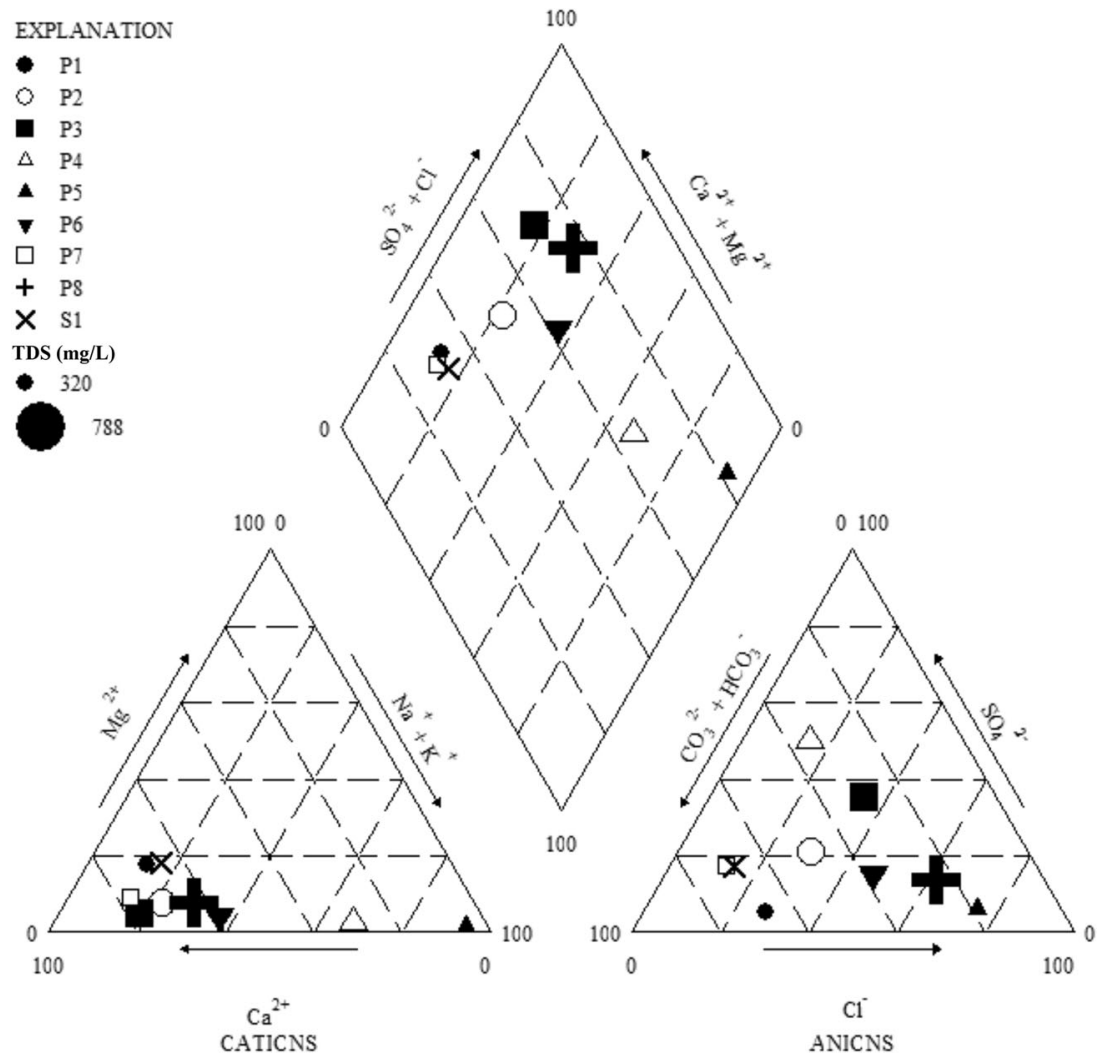

$\mathrm{Cl}$ ANICNS 


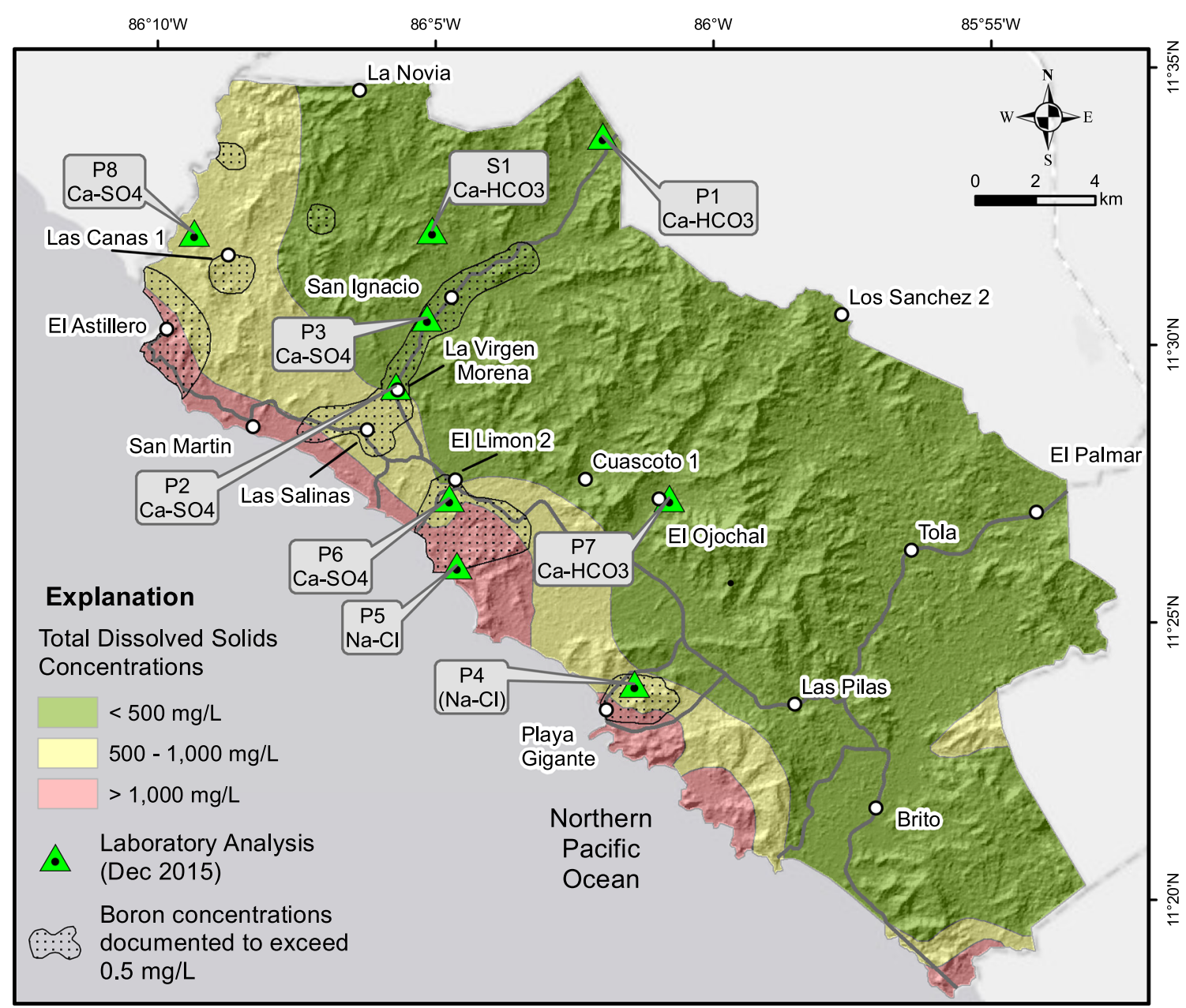

Fig. 7 Map showing (1) spatial extrapolation of total dissolved solids concentrations in groundwater, (2) groundwater type of eight wells and one spring, and (3) zones documented to have boron concentrations that exceed WHO water quality guidelines (adapted from Krásný and Hecht 1998 and Adamson 2014)

exposed to evaporation. Boron is also common in geothermal waters (Tomaszewska and Szczepański 2014), which are present in the study area. Arsenic is a contaminant of concern in volcanic and geothermal regions of Nicaragua (Gonzalez Rodriguez et al. 2018); however, it was not evaluated as part of this research.

\section{Monitoring}

\section{Hand dug wells}

In 2012, all 65 originally surveyed hand dug wells had water, however, $53 \%$ of the wells were dry during the El Niño event in 2015 . In 2016 , only $28 \%$ of the wells were dry despite the prolonged drought (Fig. 8). This can be explained in that many well owners had deepened their (dry) wells in 2015. All wells deeper than $8 \mathrm{~m}$ were recorded as dry in at least two out of the five dry seasons over the reconnaissance period. Fluctuations in water tables at individual wells between the dry season and wet season ranged from 2.5 to $14 \mathrm{~m}$, with 
Table 5 Hydrochemistry and stable isotope results from eight wells and one spring sampled in December 2015

\begin{tabular}{|c|c|c|c|c|c|c|c|c|c|c|c|}
\hline \multirow[t]{2}{*}{ Parameter } & \multirow[t]{2}{*}{ Detection Limit } & \multirow[t]{2}{*}{ Units } & \multicolumn{9}{|c|}{ Sample ID } \\
\hline & & & $\mathrm{P} 1$ & $\mathrm{P} 2$ & $\mathrm{P} 3$ & P4 & $\mathrm{P} 5$ & P6 & $\mathrm{P} 7$ & P8 & $\mathrm{S} 1$ \\
\hline Date & & & 13-Dec & & & 15-Dec & 12-Dec & & 14-Dec & 13-Dec & \\
\hline Elevation & & masl & 87 & 18 & 24 & 65 & 32 & 20 & 68 & 14 & 87 \\
\hline Alkalinity, total $\left(\mathrm{CaCO}_{3}\right)$ & 5 & $\mathrm{mg} / \mathrm{L}$ & 64 & 62 & 42 & 50 & 28 & 56 & 56 & 64 & 52 \\
\hline Alkalinity, bicarbonate $\left(\mathrm{CaCO}_{3}\right)$ & 5 & $\mathrm{mg} / \mathrm{L}$ & 64 & 62 & 42 & 50 & 28 & 56 & 56 & 64 & 52 \\
\hline Alkalinity, carbonate $\left(\mathrm{CaCO}_{3}\right)$ & 5 & $\mathrm{mg} / \mathrm{L}$ & $<5$ & $<5$ & $<5$ & $<5$ & $<5$ & $<5$ & $<5$ & $<5$ & $<5$ \\
\hline Chloride & 1 & $\mathrm{mg} / \mathrm{L}$ & 31 & 46 & 59 & 26 & 134 & 81 & 12 & 195 & 13 \\
\hline Sulfate & 15 & $\mathrm{mg} / \mathrm{L}$ & $<15$ & 42 & 79 & 115 & 15 & 36 & 22 & 57 & 21 \\
\hline Boron & 0.05 & $\mathrm{mg} / \mathrm{L}$ & $<0.05$ & 0.45 & 0.50 & 0.88 & 2.61 & 1.43 & 0.07 & 0.37 & 0.12 \\
\hline Calcium & 0.5 & $\mathrm{mg} / \mathrm{L}$ & 93.6 & 110 & 116 & 49.8 & 6.2 & 103 & 100 & 160 & 78.2 \\
\hline Magnesium & 0.5 & $\mathrm{mg} / \mathrm{L}$ & 14.5 & 7.1 & 4.3 & 2.3 & 0.9 & 4.3 & 6.9 & 11.1 & 12.9 \\
\hline Potassium & 0.5 & $\mathrm{mg} / \mathrm{L}$ & 0.8 & $<0.5$ & 0.8 & 0.9 & 5.3 & 0.7 & 0.8 & 1.3 & 1.1 \\
\hline Sodium & 0.5 & $\mathrm{mg} / \mathrm{L}$ & 20.4 & 39.9 & 30.5 & 127 & 128 & 72.6 & 20.5 & 86.0 & 22.5 \\
\hline $\mathrm{pH} @ 25^{\circ} \mathrm{C}$ & & - & 7.09 & 7.22 & 7.14 & 7.51 & 8.68 & 7.20 & 7.02 & 7.12 & 7.72 \\
\hline Conductivity & 5 & $\mu \mathrm{S} / \mathrm{cm}$ & 552 & 715 & 673 & 742 & 680 & 780 & 551 & 1230 & 515 \\
\hline Total dissolved solids & 10 & $\mathrm{mg} / \mathrm{L}$ & 326 & 484 & 470 & 510 & 380 & 520 & 320 & 788 & 363 \\
\hline$\delta \mathrm{D} \mathrm{H}_{2} \mathrm{O}$ & - & $\% o$ & -44.6 & -47.1 & -47.6 & -46.3 & -46.0 & -46.8 & -47.6 & -47.1 & -44.5 \\
\hline$\delta^{18} \mathrm{O} \mathrm{H}_{2} \mathrm{O}$ & - & $\%$ & -6.56 & -6.94 & -6.79 & -7.02 & -6.78 & -6.90 & -7.09 & -6.83 & -6.50 \\
\hline
\end{tabular}

Notes: P1-P6 are drilled wells; P7 and P8 are hand dug wells; S1 is a spring. Refer to Table 2 and Fig. 3

magnitude correlating with well depth. The median water depth for all wells is plotted in Fig. 8. (For this statistic, water levels at dry well locations were assumed to be $0.5 \mathrm{~m}$ below well depth).

Water-table elevation contours were plotted from December 2013 and November 2015 (Fig. 9). The December 2013 data represent a period at the end of the rainy season when no wells were reported dry. November 2015 data were collected during the 2015-2016 drought when over 40 wells went dry. The water table dropped significantly (as much as $7 \mathrm{~m}$ and averaging $3.5 \mathrm{~m}$ ) across the Playa Gigante area (Fig. 9).

\section{Drilled wells}

MW-01 (near Playa Gigante) was monitored starting on 24 March 2014 (Fig. 3; Table 2). The SC sensor of the logger malfunctioned on 14 June 2015 and was not replaced; however, the water level logger was maintained through 03 June 2017. During the period of monitoring, the groundwater elevation ranged from 7.05 to 0.58 masl (Fig. 10). The water table was in a steady decline and reached its lowest point just above sea level in late March 2016 during the drought. Following the peak of the drought, the water table recovered, but did not recover higher than 4.6 masl through the next year. SC ranged from 873 to $16,284 \mu \mathrm{S} / \mathrm{cm}$ during the year from which there were data. In December 2015, the well owners reported degradation of water quality, which corresponded to a water-table elevation of 3.5 masl and SC of $2,800 \mu \mathrm{S} / \mathrm{cm}$. Over the subsequent nine months, the water table continued to decline to its lowest point of 0.58 masl and SC increased to greater than $16,000 \mu \mathrm{S} / \mathrm{cm}$, indicating saltwater intrusion. While the decrease of the water table was more gradual, the increase in $\mathrm{SC}$ was sharp and occurred over a 3-week period in December 2015 when the water table fell below 3.5 masl. Following the drought, EC was measured in November

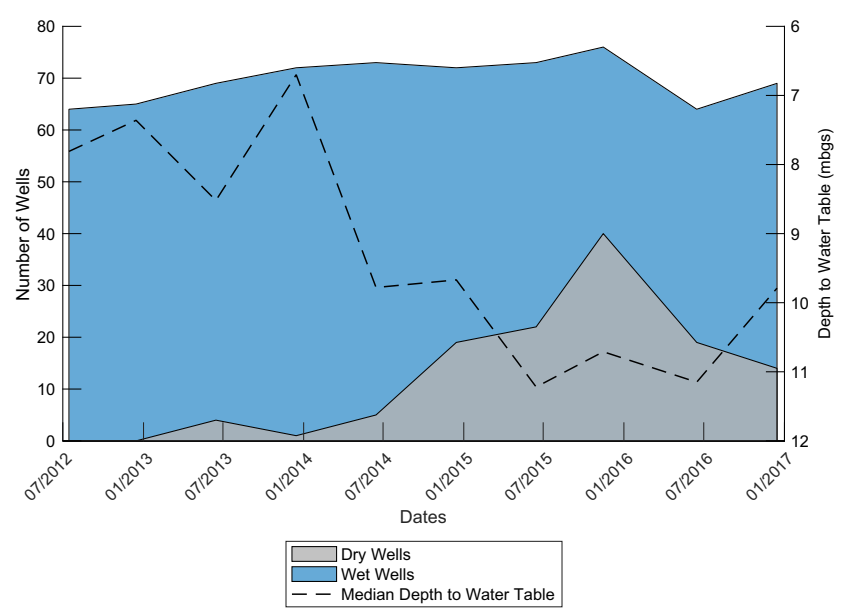

Fig. 8 Occurrence of dry hand-dug wells and median water-table depth near Playa Gigante from 2012 to 2016 

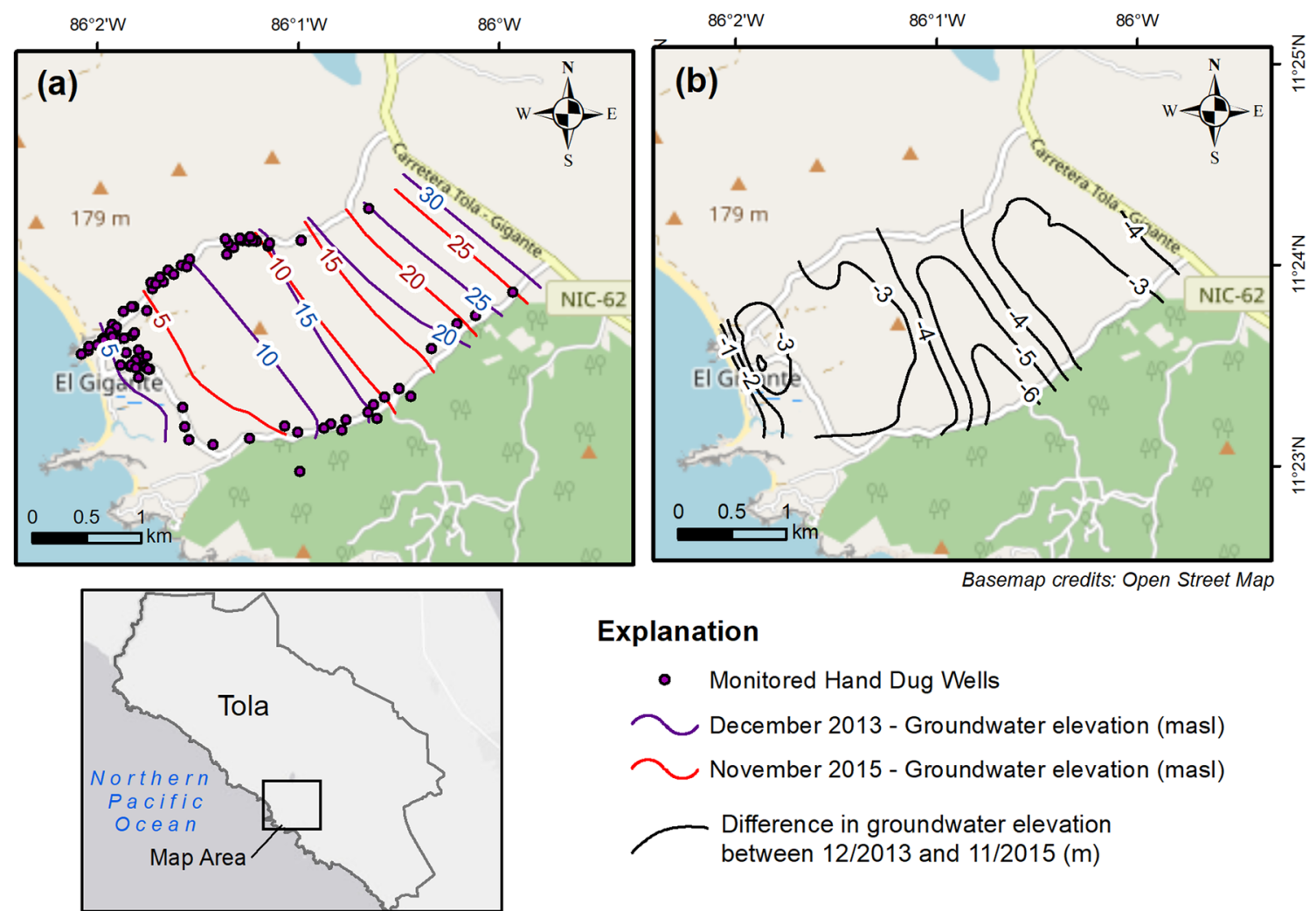

Explanation

- Monitored Hand Dug Wells

$\frown$ December 2013 - Groundwater elevation (masl)

$\frown$ November 2015 - Groundwater elevation (masl)

Difference in groundwater elevation

between 12/2013 and 11/2015 (m)

Fig. 9 Groundwater flow based on measurements of hand dug wells in Playa Gigante, a water-table elevation in December 2013 at the end of the rainy season and November 2015 during the drought, $\mathbf{b}$ difference in water table between the two snapshots

2016 at $4,233 \mu \mathrm{S} / \mathrm{cm}$, which corresponded to a water table of 3.8 masl.

MW-02 and MW-03 near Limon Dos are within $3 \mathrm{~km}$ of the coast and were monitored for 1 year (2016). Figure 11 presents a moving average of the water-table elevations which was applied to the plots to support visualization of the dataset due to daily pumping influences. Water-table elevations at MW-02 and MW-03 fluctuated 12.1 and $21 \mathrm{~m}$ (respectively) during 2016. MW-02 water elevations ranged from 3.9 to 16 masl and MW-03 ranged from -2.5 to 18.6 masl. Water levels in the wells were already in decline when monitoring started in January 2016, the lowest levels were observed during the peak of the drought in March-April 2016. MW-02 and MW-03 water levels recovered 10 and $17 \mathrm{~m}$ (respectively) within a few weeks upon the commencement of the rainy season. MW-03 experienced a sudden and unexplained $10-\mathrm{m}$ water level drop in March and again in May, which resulted in a significant decrease in pumping yield. It is hypothesized that

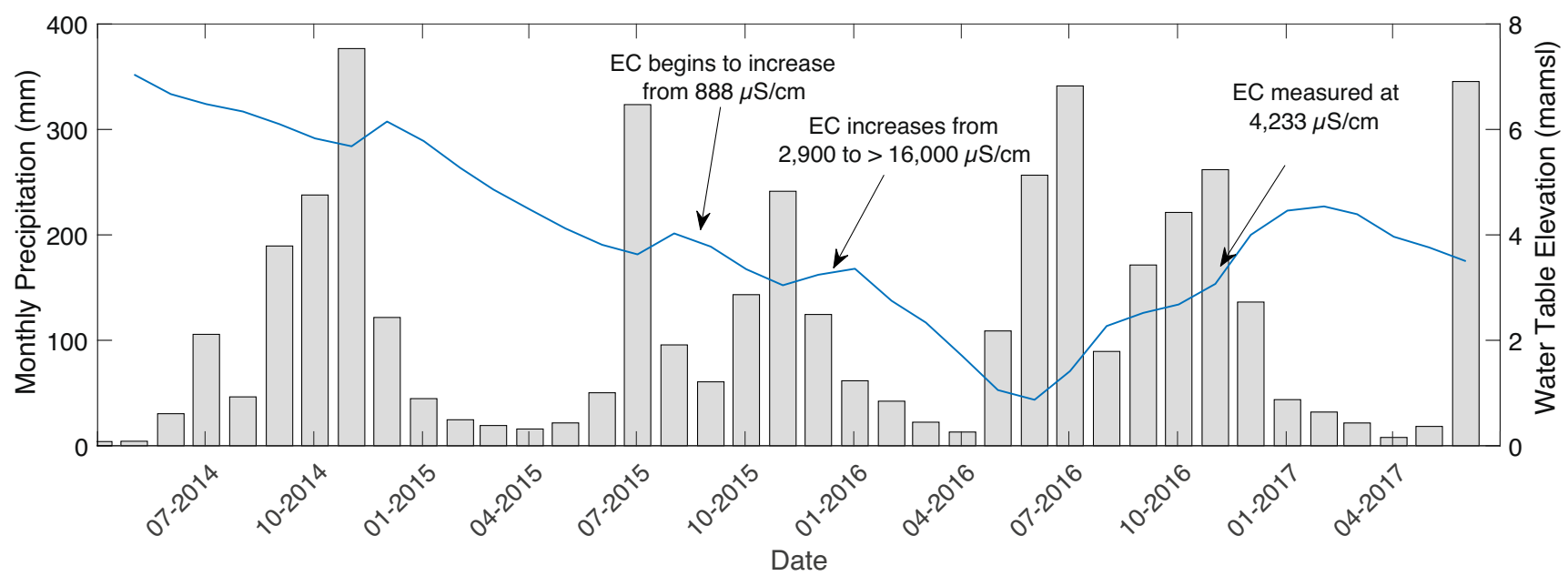

Fig. 10 Static groundwater elevations and monthly precipitation at MW-01 


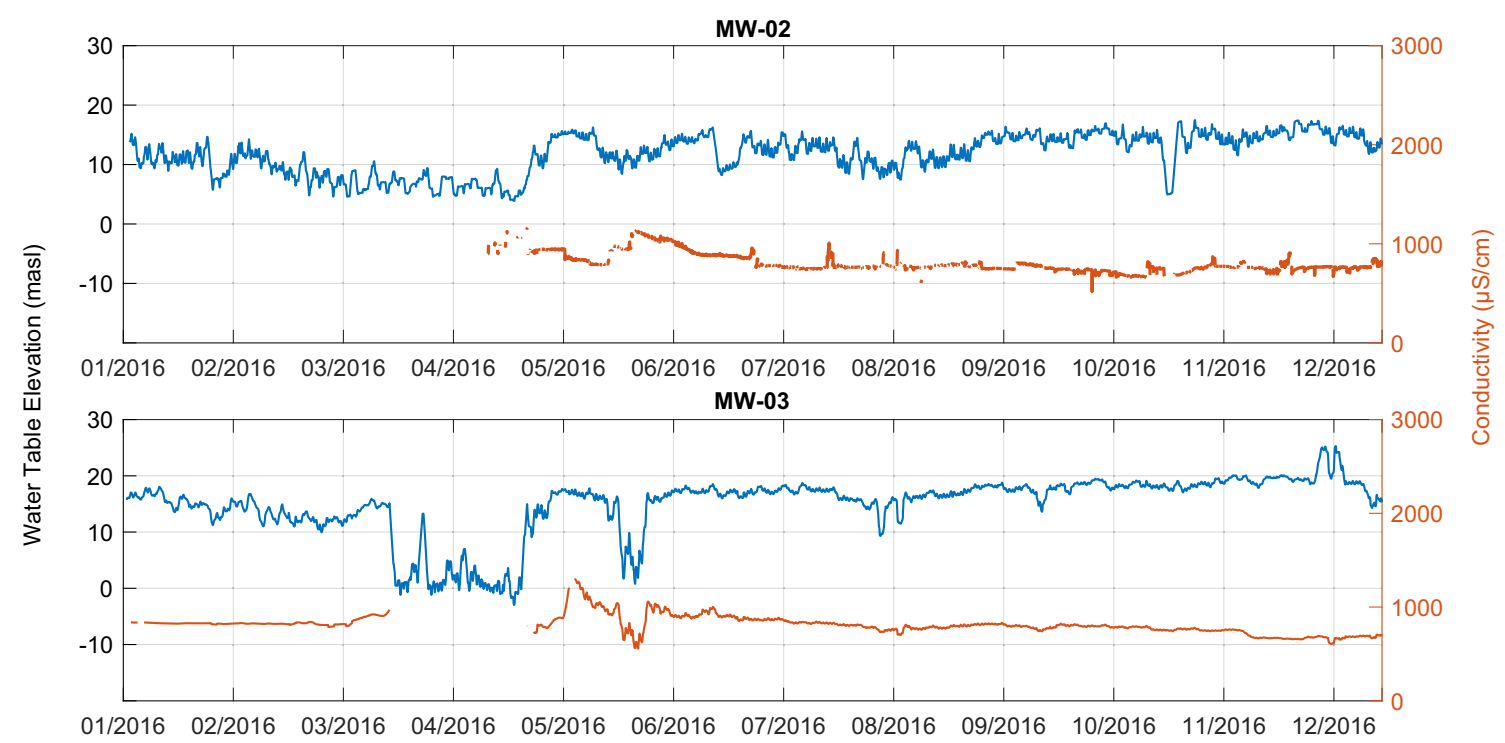

Fig. 11 Water-table elevation and specific conductance at MW-02 and MW-03 during 2016

this may have resulted from depleted storage in a fracture system, or perhaps well interference from other pumping well(s) in the area.

Specific conductance data are incomplete for the year and unfortunately do not capture the peak of the 2016 drought. (Manual measurements were not taken to document how high $\mathrm{SC}$ values may have reached). The SC ranged from 517 to $1,160 \mu \mathrm{S} / \mathrm{cm}$ at MW-02 and 617 and $1,273 \mu \mathrm{S} / \mathrm{cm}$ at MW-03 (Fig. 11). The higher SC does appear to be associated with the dry season and lower water tables, and there is an inverse correlation between SC and water-table elevation.

In both Playa Gigante and El Limon Dos, hydraulic gradients, as calculated between well locations and the coast, ranged significantly from near zero to 0.01 during the period of monitoring. The gradient associated with MW-01 (in Playa Gigante) was inversely correlated to SC, exhibiting the relationship with water tables and seawater mixing.

\section{Chloride and mass balance}

Chloride concentrations of rainfall samples collected $(n=16)$ were between 2.7 and $24.3 \mathrm{mg} / \mathrm{L}$, averaging $11.4 \mathrm{mg} / \mathrm{L}$ (Table 6). The volume weighted mean concentration of chloride in rainfall was $8.12 \mathrm{mg} / \mathrm{L}$. A moderate inverse correlation exists between chloride concentrations and daily rainfall totals.

A chloride mass-balance (CMB) was applied to derive a planning-level estimate of groundwater recharge in the study area. The CMB equation is defined in Eq. (1), where $R$ is recharge ( $\mathrm{mm} /$ year), $P$ is rainfall $\left(\mathrm{mm} /\right.$ year), $\mathrm{Cl}_{\mathrm{p}}^{-}$is average chloride concentration in rainfall $(\mathrm{mg} / \mathrm{L})$, and $\mathrm{Cl}^{-}$gw is average chloride concentration in groundwater $(\mathrm{mg} / \mathrm{L})$.

$$
R=P \times \frac{\mathrm{Cl}_{\mathrm{p}}^{-}}{\mathrm{Cl}_{\mathrm{gw}}^{-}}
$$

Table 6 Chloride concentrations of rainfall in Tola municipality, Nicaragua

\begin{tabular}{lll}
\hline Date & $\begin{array}{l}\mathrm{Cl}^{-} \\
(\mathrm{mg} / \mathrm{L})\end{array}$ & $\begin{array}{l}\text { Precipitation }^{\mathrm{a}} \\
(\mathrm{cm})\end{array}$ \\
\hline 20-Mar-2014 & 19 & 0.90 \\
26-Aug-2014 & 4.6 & 11 \\
23-Sep-2014 & 22 & 1.36 \\
15-Nov-2014 & 17.4 & 1.86 \\
09-Jun-2015 & 5 & 1.0 \\
10-Jun-2015 & 16 & 1.76 \\
11-Jun-2015 & 12.4 & 3.8 \\
26-Sep-2015 & 7.7 & 4.2 \\
08-Oct-2015 & 15.2 & 0.04 \\
22-Oct-2015 & 5.2 & 4.3 \\
20-Nov-2015 & 2.7 & 1.12 \\
12-Jan-2016 & 13.3 & 0.76 \\
06-May-2016 & 5.62 & 5.96 \\
11-Jun-2016 & 7.1 & 2.84 \\
18-Jul-2016 & 24.3 & 0.60 \\
29-Aug-2016 & 5.5 & 3.88 \\
\hline
\end{tabular}

Note: Samples collected in Playa Gigante at 17 masl within $1 \mathrm{~km}$ of the coast

${ }^{\mathrm{a}}$ Total daily precipitation as recorded at private rain gauge at El Limon Dos

${ }^{\mathrm{b}}$ Samples collected near E1 Limon Dos, at 12 masl, $250 \mathrm{~m}$ from the coast 


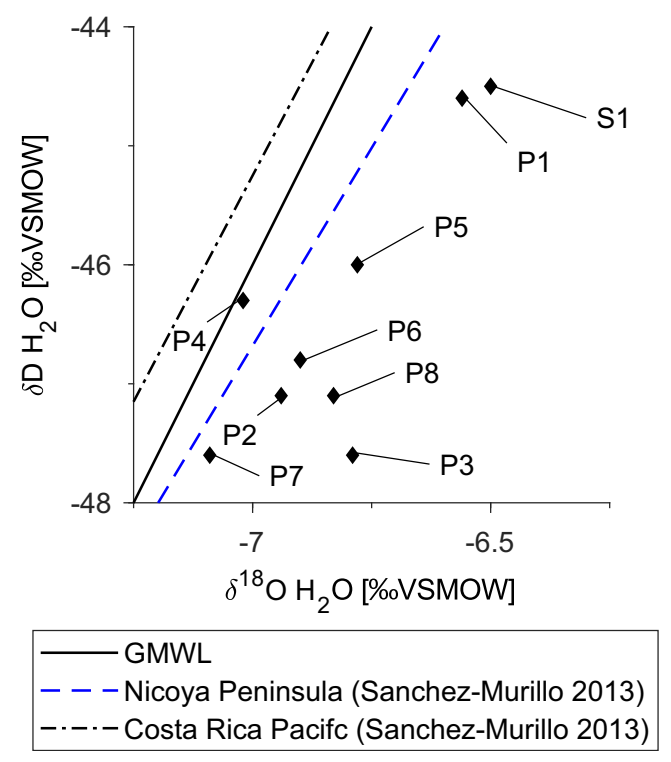

Fig. 12 Relationship between deuterium (D) and oxygen-18 with global and local meteoric water lines. Regional meteoric water lines of Costa Rica from Sánchez-Murillo et al. (2013)

Chloride data were available for nine groundwater samples, three of which were omitted from analysis (P8 is a hand dug well with higher EC $(1,230 \mu \mathrm{S} / \mathrm{cm})$ than the other samples, and $\mathrm{P} 4$ and $\mathrm{P} 5$ exhibit $\mathrm{Na}-\mathrm{Cl}$ hydrochemistry and are interpreted to have seawater influence). Applying the volume weighted average chloride concentration of rainfall (Table 6) and $52.5 \mathrm{mg} / \mathrm{L}$ as the average chloride concentration of groundwater, $\mathrm{CMB}$ results indicate mean annual groundwater recharge is $17 \%$ of average annual precipitation, or $258 \mathrm{~mm} /$ year.

\section{Stable isotopes}

The stable isotope values measured from wells $(n=8)$ and a spring $(n=1)$ in Tola form a narrow range from -7.09 to -6.5 per mil $\partial^{18} 0$, and -47.6 to -44.5 per mil $\partial \mathrm{D}$. These data are plotted in Fig. 12 with the Global Meteoric Water Line $(\partial \mathrm{D}=$ $\left.8 \partial^{18} \mathrm{O}+10\right)$ and two meteoric water lines representative of the Nicoya Peninsula $\left(\partial \mathrm{D}=6.65 \partial^{18} \mathrm{O}-0.131\right)$ and Pacific Coast $\left(\partial \mathrm{D}=7.6 \partial^{18} \mathrm{O}+7.95\right)$ regions in Costa Rica (SánchezMurillo et al. 2013). Across the Tola municipality, the waters mostly lie beneath meteoric water lines, indicating evaporation exposure before or during recharge. Well P1 and spring $\mathrm{S} 1$ are farthest inland and more enriched than the other samples. Wells P4 and P7 could be more representative of direct recharge as they plot closer to the meteoric lines. P7 is the most depleted of the samples and P4 falls slightly above the Nicoya Peninsula meteoric water line but below the others (Fig. 12). $\partial^{18} \mathrm{O}$ values were plotted against discharge or water-table elevations and showed a lack of linearity and slight trend of elevation dependency among lower elevation sample subsets. This lack of linearity indicates that discharge elevations are lower than mean recharge elevations.

\section{Petrology and rock properties}

The rocks of the Brito Fm observed at outcrops in Tola are predominately sandstones; however, they exhibit significant diversity. Primary porosity is low based on samples $(n=10)$ collected from outcrops and bottom of dry hand dug wells with results ranging from 0.22 to $3.14 \%$ (Table 7 ). The highest porosity value of $3.14 \%$ represented a semiconsolidated sandstone with a scan that showed minimal interconnectedness between voids (Fig. 13). Samples with increased porosity resulted from microchannels and/or zeolite voids.

The categories of sandstone include lithic wackes, felspathic arenites, lithic arenites, and sublitharenites (Table 7). The rocks are of volcanogenic origin with tuffaceous fabric, zeolites, glass, and pumice fragments. Hand samples and scans exhibited cross-bedding, microchannels, and zeolite voids. The dominant minerals are quartz (11.55$83.4 \%)$, plagioclase feldspar $(2.74-32.58 \%)$, calcite $(0.03-$ $23.08 \%)$, carbonate-clay interphase $(0.53-13.80 \%)$, chlorite (1.08-12.94\%), smectite, (0.49-10.05\%), dolomite (0.04$0.81 \%$ ), and illite (Table 7; Fig. 13). A lithic wacke (ID 6) had significantly less quartz and more chlorite, plagioclase, and illite than any of the other samples. The results show variable grades of diagenesis based on analysis of thin sections and mineral content, which may have an influence on the presence, availability and quality of groundwater.

\section{Geological attitude}

Strike and dip measurements of Brito Fm beds were made at 51 locations throughout the Tola municipality (Fig. 3). Regionally, the Brito Fm strikes SE and beds are uniformly dipping and planar in the SW direction towards the coast $\left(\overline{\mathrm{x}}=226^{\circ}, \mathrm{SD}=62^{\circ}\right)$. Beds dip at angles ranging from 5 to $30^{\circ}\left(\overline{\mathrm{x}}=16^{\circ}, \mathrm{SD}=5^{\circ}\right.$; Fig. 14). Fifteen percent of measurements exhibited localized folding and offsets due to jointing and faulting, resulting in dip azimuths ranging from 14 to $365^{\circ}$ (Fig. 14a). The uniform and planar geological attitude of the Brito Fm aligns with the direction of groundwater flow and orientation of major lineaments $\left(198-235^{\circ}\right)$.

\section{Discussion}

\section{Aquifer and groundwater system}

In the Tola municipality, the Brito Fm supports two primary aquifer zones which include an unconfined upper section in fractured and weathered rock, and a lower confined section in deeper fracture networks. Based on drilling logs and well test 


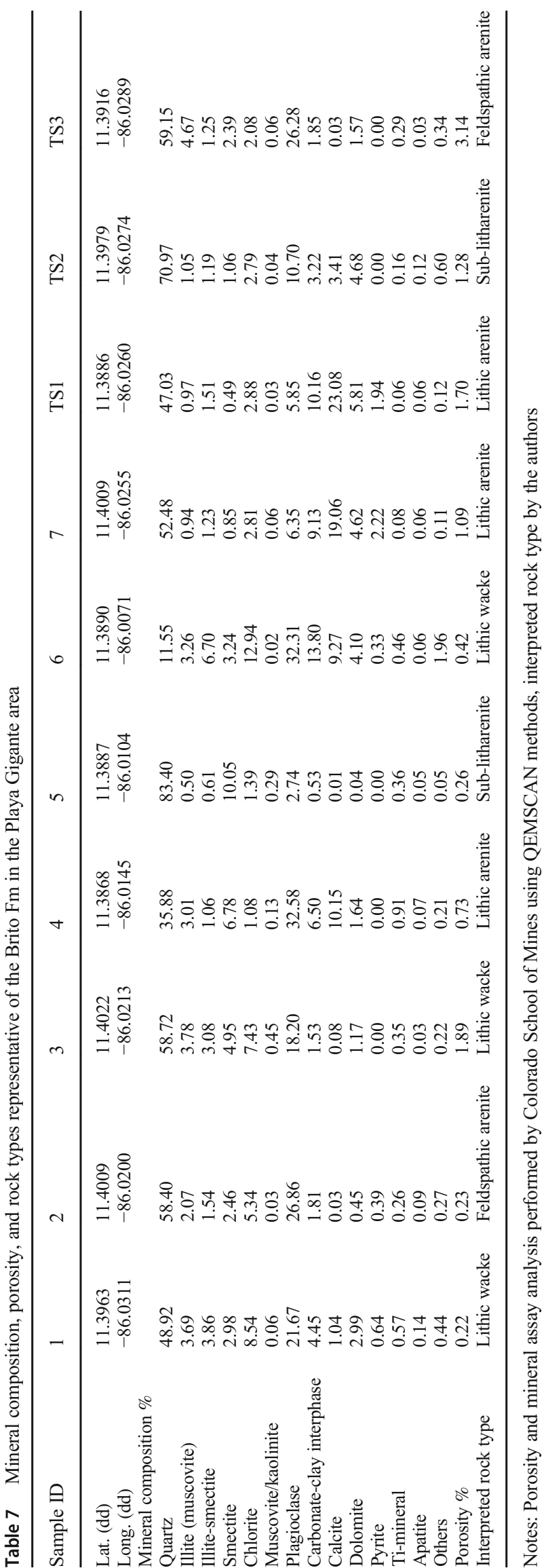

data, the shallow portion, where present, is up to $30 \mathrm{~m}$ below land surface and supports most of the hand dug wells in Tola. The deeper section is documented with boreholes up to $260 \mathrm{~m}$, with production from fracture porosity at variable depths. The formation thickens westerly towards the coast and is bounded below and to the north and east by the Rivas Formation of Cretaceous age. Volcanic intrusions of Tertiary age are believed to underlie the Brito Fm; however, the only mapped outcrop is in NE Tola where the Brito Fm is absent. The regional flow system suggests an interconnection with the Rivas Formation along the Brito Valley and in the NE of study area. Unconsolidated sediments up to $15 \mathrm{~m}$ thick overlie the Brito Fm in valleys and coastal areas. These sediments may serve an important role in capturing streamflow and runoff, and buffering inflow to the bedrock aquifer system.

The hydraulic gradient is westerly towards the coast, steeper in the hills, and lower in the coastal plain and valleys. Regional groundwater flow mirrors the true dip direction of the beds, and topographic influence is evident in the larger valleys. During most of the year, the piezometric surface is lower than the streams and rivers, except in closer proximity to the coast. Water-table depths in the upper section are typically less than $30 \mathrm{~m}$ and monitoring results indicate seasonal fluctuations ranging between 2.5 to $14 \mathrm{~m}$. The magnitude of fluctuations is more significant at wells with shallow water tables. The deeper zone as represented by records from drilled wells have piezometric surfaces recorded as deep as $53 \mathrm{~m}$ in the upland hills, and as shallow near the sea elevation in proximity to the coast. Fluctuations in the piezometric surfaces were documented to be $6.5,12$, and $21 \mathrm{~m}$ at three drilled wells (with corresponding increases in EC). These fluctuations were magnified by the 2015-2016 drought.

There is spatial and vertical heterogeneity of the aquifer system that influences availability of groundwater, flow dynamics, recharge, and water quality. The specific yield of hand dug wells averaged 0.21 and ranged from 0.04 to 0.3 based on analysis of 61 hand dug wells in Tola (Unpublished data). The deeper zone exhibits hydraulic conductivity that ranges by 3 orders of magnitude $(0.05-90 \mathrm{~m} /$ day $)$ and storativity that spans 2 orders of magnitude (0.003-0.001). The highest quartile of hydraulic conductivity of drilled wells has piezometric surface elevations less than $10 \mathrm{~m}$ and is in areas with topographic expressions of geological structure. The water quality illustrates spatial variability primarily based on position in the regional flow system, and by the varying permeability of the aquifer. Weathering processes and ion releases from the rocks to the groundwater are higher in areas with lower permeability due to longer residence times. Gypsum and marine aerosols present in less permeable sedimentary rocks may explain the sulfate hydrochemistry in some areas. There are also seawater and geothermal influences on the water quality near the coast and in the northern coastal plain, respectively. 
Fig. 13 Mineral assay results of Brito Formation rocks using QEMSCAN
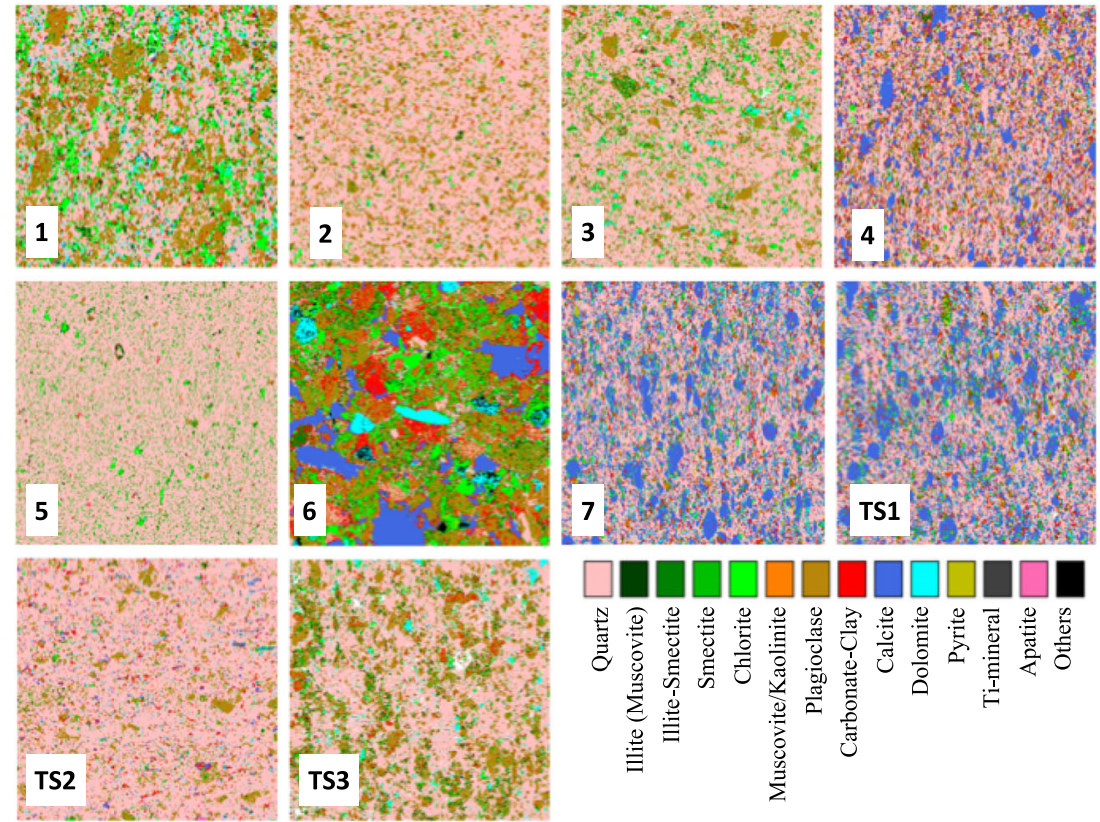

\section{Aquifer storage and porosity}

Secondary porosity has significant influence on groundwater flow and availability. Results revealed that primary porosity of near surface Brito Fm rocks is low $(0.22-3.14 \%)$ and $1-2$ orders of magnitude less than values applied in various private-sector consulting reports that have been reviewed by the authors. Groundwater storage and associated availability is thus significantly less than previously assumed for the study area and is more dependent on secondary porosity by way of fracture networks and structural features (e.g. faults and joints). Water level data, chemical and isotopic characteristics of sampled groundwater, and aquifer properties are indicative of a heterogenous fractured aquifer system. This storage characteristic may contribute to vulnerability of the aquifer to overexploitation and drought, as demonstrated by monitoring data from the areas of Playa Gigante and El Limon Dos where there is a higher density of pumping wells.
The variable petrology of near surface rocks within a small area suggests complex diagenesis processes have influenced the porosity and permeability of the aquifer. Spinelli et al. (2006) documented changes in rock properties resulting from diagenesis processes in neighboring Costa Rica and noted the magnitude of changes depend on factors such as sediment makeup, fluid pressures, heat, and compaction. The sandstone facies documented in Tola are recrystallized, of later stage diagenesis with a low proportion of zeolites, typically have no primary porosity, and are more brittle and prone to fracturing and the development of secondary porosity. Earlier stage diagenesis rocks with a high proportion of clays and feldspars have volcanic parentage with abundant zeolites, glass, and pumice fragments. These rocks are typically softer and more ductile and promote lower secondary porosity, as these types of rocks are less likely to house the open fractures which promote recharge and storage.
Fig. 14 Rose diagrams of geological attitude from 51 stations throughout Tola. In both plots, segments are proportional to the percentage of measurements that fall within each $5^{\circ}$ interval
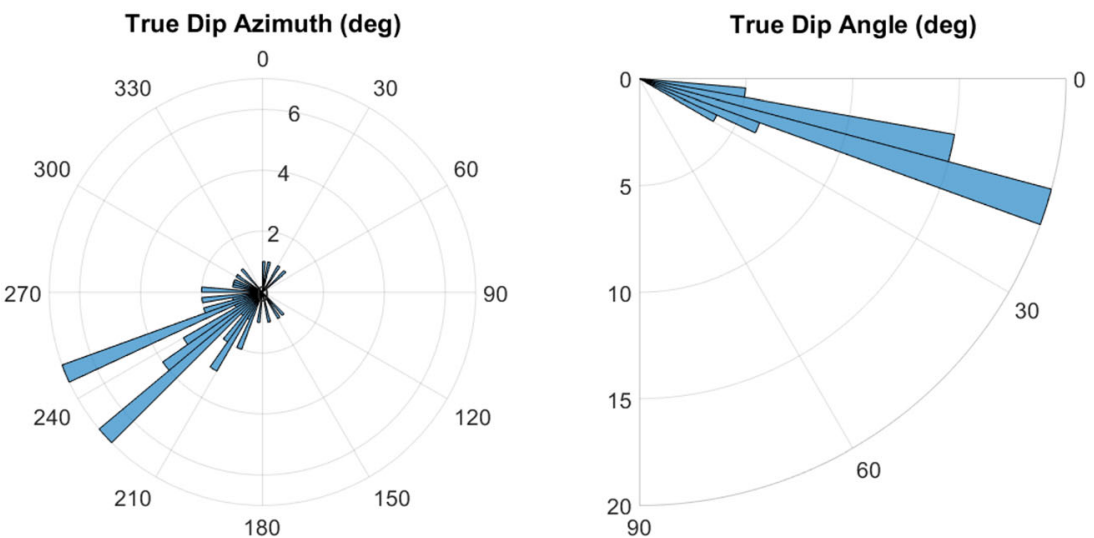
Fig. 15 Groundwater elevations and monthly precipitation and evapotranspiration near Playa Gigante (Tola municipality, Nicaragua)

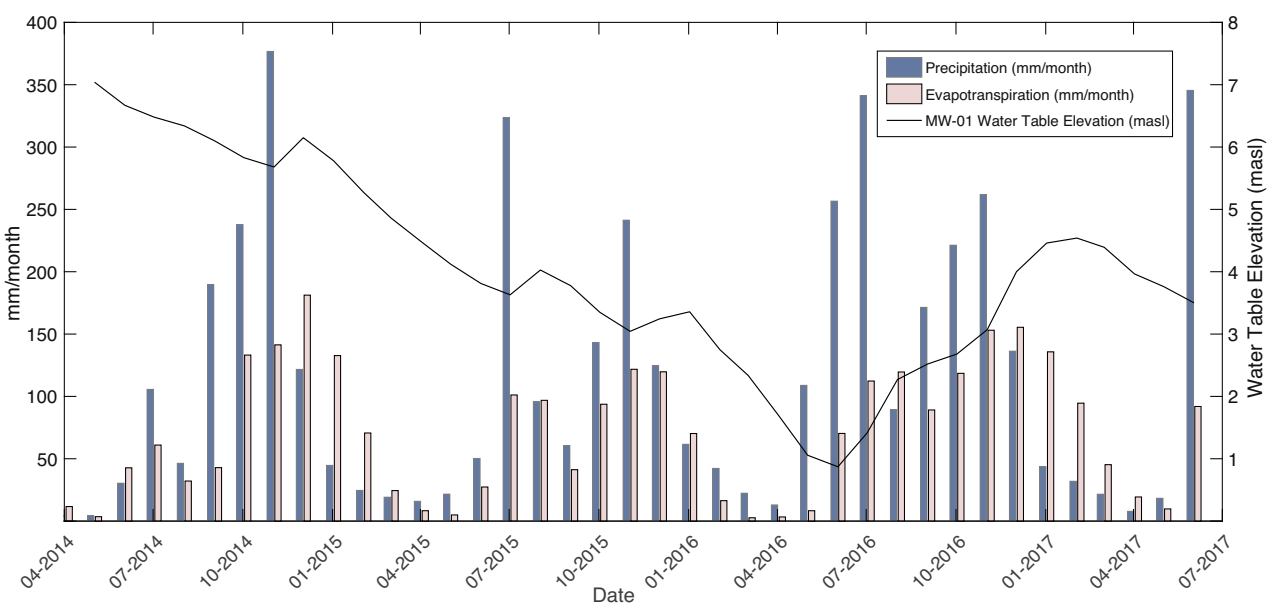

\section{Recharge and discharge processes}

Isotopic signatures indicate that groundwater in most drilled and hand dug wells was exposed to evaporation before or during recharge, suggesting infiltration from rivers and concentrated runoff events are a large source of recharge. Direct recharge is likely limited due to the low infiltration capacity of Brito Fm soils (Calderón and Uhlenbrook 2016).

The planar and uniform coastward dipping geological attitude of the Brito Fm and the orientation of structural lineaments generally promote short residence times and efficient transmission of groundwater flow from recharge areas to the ocean. The anticline axis associated with the ridge of the Pacific Hills near the eastern edge of Tola (Fig. 1) may limit recharge as the Brito Fm dips easterly and away from the Pacific Coast east of this axis.

This study indicates long-term mean annual recharge is on the order of $258 \mathrm{~mm} /$ year; however, the range of chloride and isotopic signatures in groundwater indicates high spatial variability in recharge occurrence, which may be perhaps as low as $60 \mathrm{~mm} /$ year in some areas. A larger proportion of recharge is believed to occur in low-lying areas and drainages where streamflow and runoff has the opportunity to be infiltrated. These areas also correspond to where the bedrock has higher porosity and permeability, further enhancing the localization of recharge during rainfall events sufficient to generate runoff.

Recharge is also temporally variable. A significant proportion may result from large precipitation events early in the rainy season when soil moisture is low, water tables are deeper, and ET is lower. At MW-01 in Playa Gigante, high precipitation and low ET early in the 2016 rainy season correlated to the only rise in the water table over the preceding 14 months (Fig. 15). Figure 15 also illustrates water-table rises only occurring when monthly precipitation was greater than $250 \mathrm{~mm}$. It is worth noting that MW-02 and MW-03 near El Limon Dos also had a similar relationship between monthly precipitation and water-table fluctuation.
In the study area, water-table elevations are lower than the ephemeral and intermittent streams for most of the year and little groundwater discharges to these channels. The larger rivers are believed to receive groundwater discharge for some portions of the year, especially towards the coast, and during the rainy season when groundwater levels are higher. Perennial discharge occurs from the aquifers to the lower sections of the Brito and Nagualapa rivers and brackish ecosystems near the coast. Groundwater discharge also occurs at wells throughout the study area and some small springs. The Pacific Ocean is the largest discharge component for the aquifer system.

\section{Vulnerabilities}

Several factors contribute to the water security vulnerabilities in Tola. First, groundwater recharge is limited and lacking spatial and temporal homogeneity. Despite a mean annual precipitation range of $1,292-1,618 \mathrm{~mm} /$ year, renewable groundwater for Tola is perhaps on the order of $2,300 \mathrm{~L} / \mathrm{s}$, or $8 \mathrm{~L} / \mathrm{s}$ per square kilometer. Secondly, the low bulk aquifer storage and coastal discharge precludes a savings account to buffer the system from drought, increased abstraction from the tourism sector, and climate change. This factor is particularly salient given the tendency of strong El Niño events, predicted climate change, and likely increase in tourism development. Thirdly, the orientation of the regional groundwater flow system strongly influences groundwater chemistry, thus rendering both groundwater quantity and quality at risk from drought, increased abstraction, and climate change.

Some of these vulnerabilities were strongly demonstrated during the 2015-2016 El Niño drought when groundwater elevations in both shallow and deep aquifer zones dropped significantly (up to $21 \mathrm{~m}$ ). Over $50 \%$ of monitored hand dug wells went dry, and drilled wells had water levels below pump depths, or required significantly reduced pumping rates. Water quality impacts were also pronounced, with EC 
doubling at two wells, and increasing nearly 16-times at another monitoring well. For nearly 1 year, the quality of groundwater in many wells near Playa Gigante was not potable until the arrival of the 2016 rains. Water quality impacts were also reported inland where water temperatures, salinity, and sulfur odors increased in the Nagualapa Valley during the drought. Given that flowing hot springs are present at the lower end of the valley near the coast, this may indicate the displacement of fresher groundwater with geothermal waters. The higher boron concentrations mapped in this area and Nagualapa valley (Fig. 7) may also indicate geothermal influence on the aquifer waters (Tomaszewska and Szczepański 2014).

\section{Conclusion}

Lack of groundwater data and aquifer characterization are a key challenge to sustainable development in SW Nicaragua, and indeed to many global regions growing in reliance upon groundwater. Although the national water law of Nicaragua (Ley 620 of 2007) established water as a public good and provided a framework for the state to ensure its role in social, environmental, and economic well-being, limited hydrogeological knowledge exists in SW Nicaragua to support these aims. The goal of this study has been to advance characterization of the Brito Fm aquifer system to provide a stronger base to support tourism development, rural communities, and the capacity of the government to manage water amidst complexities of growing demand and climate change. The challenges and vulnerabilities associated with the groundwater resources have been documented and interpreted in this paper and its Open Access publication enables dissemination to stakeholders, researchers, and practitioners. As the hydrogeology of the aquifer systems are better understood, the invaluable resources can be more sustainably developed and managed.

Increased abstraction and climate change will continue to stress the Tola region, thus resiliency planning is necessary at all scales to avert drought induced crises. In the interim, watershed and local-scale practices should be considered to enhance groundwater recharge in the region. Further study and monitoring are essential given the diverse hydrogeological, climatic, and social factors that make groundwater resources extremely vulnerable to drought. Regional-scale studies should avoid administrative boundaries as study areas and evaluate hydrogeological interconnections between the Brito and Rivas formations in Pacific Nicaragua. Inland groundwater/surface-water interactions between the bedrock aquifer systems and perennial rivers such as the Brito are also important to evaluate to determine if there are more significant sources of streamflow infiltration occurring in the region. In the absence of (1) continued knowledge building, (2) informed groundwater management, and (3) relevant government involvement, groundwater availability in Tola will likely be a progressively limiting factor in physical and economical human development.

Acknowledgements The authors thank three reviewers (two anonymous and Dr. Laurence R. Bentley) and the associate editor for their comments and insightful suggestions which greatly improved the manuscript. We are grateful to Instituto Nicaragüense de Estudios Territoriales (INETER), Universidad Nacional Autónoma de Nicaragua (UNAN), and Living Water International (LWI) for data collection efforts and generously making information available. Thanks to HydroLOGICA, S.A. for expertise and experienced well drilling in the region. Special thanks also to those that supported data collection and research activities over the years, including Alan Vilchez, Dr. Jeffrey Greenberg, Jonas Bernasconi, Wm. Javan Miner, Sarah Young, and Guillermo Zepeda.

Funding Information Thanks to Michael Montgomery for supporting some of the research expenses.

Open Access This article is licensed under a Creative Commons Attribution 4.0 International License, which permits use, sharing, adaptation, distribution and reproduction in any medium or format, as long as you give appropriate credit to the original author(s) and the source, provide a link to the Creative Commons licence, and indicate if changes were made. The images or other third party material in this article are included in the article's Creative Commons licence, unless indicated otherwise in a credit line to the material. If material is not included in the article's Creative Commons licence and your intended use is not permitted by statutory regulation or exceeds the permitted use, you will need to obtain permission directly from the copyright holder. To view a copy of this licence, visit http://creativecommons.org/licenses/by/4.0/.

\section{References}

Abbott SP (2013) Hand dug Wells: choice of technology and construction manual. World Bank Group, Washington, DC

Adamson J (2014) GIS supported hydrogeological analysis of the Tola Municipio, Nicaragua. Paper 36-5, Geological Society of America 2014 Annual Meeting, Vancouver, BC

Astorga A (1987) El Cretácico Superior y el Paleógeno de la vertiente Pacifica de Nicaragua meridional y Costa Rica septentrional: Origen, evolución y dinámica de las cuencas profundas relacionadas al margen convergent de Centroamérica [The Upper Cretaceous and the Paleogene of the Pacific slope of southern Nicaragua and northern Costa Rica: origin, evolution and dynamics of the deep basins related to the convergent margin of Central America]. MSc Thesis, Univ. Costa Rica, San José, Costa Rica, 115 pp

Astorga A (1988) Geodinámica de las cuencas del Cretácico superiorPaleógeno de la región "forecarc" del Sur de Nicaragua y Norte de Costa Rica [Geodynamics of the upper Cretaceous-Paleogene basins of the "forearc" region of southern Nicaragua and northern Costa Rica]. Rev Geol Amer Cent 9:1-40

Becken S (2014) Water equity: contrasting tourism water use with that of a local community. Water Res Indust 7-8:9-22. https://doi.org/10. 1016/j.wri.2014.09.002

Bouwer H (1978) Groundwater hydrology. McGraw-Hill, New York, $480 \mathrm{pp}$ 
Bracci LZ, Gludace DD (1958) Geologia de la Costa del Pacifico de Nicaragua [Geology of the Pacific coast of Nicaragua]. Bol Serv Geol Nacional Nicaragua 1, 1959

Calderón H, Uhlenbrook S (2016) Characterizing the climate water balance dynamics and different runoff components in a poorly gauged tropical forested catchment, Nicaragua. Hydrol Sci J 61(14):24652480. https://doi.org/10.1080/02626667.2014.964244

Calderón Palma H, Bentley LR (2007) A regional-scale groundwater flow model for the Leon-Chinandega aquifer, Nicaragua. Hydrogeol J 15:1457-1472. https://doi.org/10.1007/s10040-0070197-6

Collins WJ, Bellouin N, Doutriaux-Boucher M, Gedney N, Halloran P, Hinton T, Hughes J, Jones CD, Joshi M, Liddicoat S, Martin G, O'Connor F, Rae J, Senior C, Sitch S, Totterdell I, Wiltshire A, Woodward S (2011) Development and evaluation of an earthsystem model HadGEM2. Geosci Model Dev Discuss 4:9971062. https://doi.org/10.5194/gmdd-4-997-2011

Connors JP, Lei S, Kelly M (2012) Citizen science in the age of neogeography: utilizing volunteered geographic information for environmental monitoring. Ann Assoc Am Geogr 102(6):1267-1289

Corriols M, Nielsen MR, Dahlin T, Christensen NB (2009) Aquifer investigations in the León-Chinandega plains, Nicaragua, using electromagnetic and electrical methods. Near Surf Phys 7(5-6):413426. https://doi.org/10.3997/1873-0604.2009034

Darce M, Baca D, Duarte M (2000) New law, seismic information smooth Nicaragua licensing. Oil Gas J 98:72-74

Domenico PA, Schwartz FW (1990) Physical and chemical hydrogeology. Wiley, New York

ENACAL (Empresa Nicaraguense de Acueductos y Alcantarillados) (2006) Estudio hidrogeologico de pozos en La Virgen, Tola, Rivas [Hydrogeological study of wells in La Virgen, Tola, Rivas]. ENACAL, Managua, Nicaragua

Fick SE, Hijmans RJ (2017) WorldClim 2: new 1-km spatial resolution climate surfaces for global land areas. Int J Climatol 37:4302-4315. https://doi.org/10.1002/joc.5086

Freeze RA, Cherry JA (1979) Groundwater. Prentice Hall, Englewood Cliffs, NJ

Gonzalez Rodriguez B, Rietveld LC, Longley AJ, van Halem D (2018) Arsenic contamination of rural community wells in Nicaragua: a review of two decades of experience. Sci Total Environ 657:14411449. https://doi.org/10.1016/j.scitotenv.2018.12.168

Heath RC (1983) Basic ground-water hydrology. US Geol Surv Water Suppl Pap 2220, 86 pp

Hoffstetter R, Dengo G, Weyl R (1960) Costa Rica. In: Hoffstetter R (ed) Lexique stratigraphique international, Amérique Central [International stratigraphic lexicon, Central America). Fascícul. 2.5, Centre National de la Recherche Scientifique (CNRS), París, pp 223-306

Huffman GJ, Stocker EF, Bolvin DT, Nelkin EJ, Tan J (2019) GPM IMERG Final Precipitation L3 1 month 0.1 degree $\times 0.1$ degree V06, Greenbelt, MD, Goddard Earth Sciences Data and Information Services Center (GES DISC). Accessed 17 October 2019. https://doi.org/10.5067/GPM/IMERG/3B-MONTH/06

Imbach P, Chou SC, Lyra A, Rodrigues D, Rodriguez D, Latinovic D, Siqueira G, Silva A, Garofolo L, Georgiou S (2018) Future climate change scenarios in Central America at high spatial resolution. PLoS One 13(4):e0193570. https://doi.org/10.1371/journal.pone.0193570

Instituto Nicaragüense de Energia (INE) (2002) Mapa Geologico de la Cuenca Sandino Pacifico de Nicaragua [Geological map of the Sandino Pacific Basin of Nicaragua]. Scale 1:175,000, 1 sheet, INE, Managua, Nicaragua

Instituto Nicaragüense de Estudios Territoriales (INETER) (1988) Elaboración de geológico con mapas topográficos [Preparation of geological with topographic maps]. Scale: 1:50,000, INETER, Managua, Nicaragua
Instituto Nicaragüense de Estudios Territoriales (INETER) (2016) Meteorological Data. Available online: http://www.ineter.gob.ni/. Accessed 17 May 2017

Krásný J, Hecht G (1998) Estudios hidrogeológicos e hidroquímicos de las Región del Pacífico de Nicaragua [Hydrogeological and hydrochemical studies of the Pacific Region of Nicaragua]. COSUDE, INETER, GTZ, Managua, Nicaragua, $154 \mathrm{pp}$

Kumpulainen RA (1995) Stratigraphy and sedimentology in western Nicaragua. Rev Geol Amér Central 18:91-94

LaVanchy GT (2017) When wells run dry: water and tourism in Nicaragua. Ann Tour Rsch 64:37-50

LaVanchy GT, Romano S, Taylor MJ (2017) Challenges to water security along the "Emerald Coast": a political ecology of local water governance in Nicaragua. Water 9:655

LaVanchy GT, Taylor MJ, Alvarado NA, Sveinsdóttir AG, AguilarStøen MA (2020) Tourism in post-revolutionary Nicaragua. Springer, Heidelberg, Germany

Levi B, Kumpulainen RA, Darce M (1995) Diagenesis in the Volcaniclastic sequences of western Nicaragua: mineralogical breaks and tectonic implications. Rev Geol Amér Central 18:87-90

McBirney AR, Williams H (1965) Volcanic history of Nicaragua. Univ Calif Pub Geol Sci 55:73

Moncrieff JE, Bentley LR, Calderón Palma H (2007) Investigating pesticide transport in the León-Chinandega aquifer, Nicaragua. Hydrogeol J 16:183-197. https://doi.org/10.1007/s10040-0070229-2

Parsons Corporation (1972) The geology of western Nicaragua. Nicaragua tax improvement and natural resources inventory project, Final technical report, vol IV, Managua, Nicaragua, Parsons, Centreville, VA, $220 \mathrm{pp}$

Quesada-Hernández LE, Calvo-Solano OD, Hidalgo HG, Pérez-Briceño PM, Alfaro EJ (2019) Dynamical delimitation of the Central American dry corridor (CADC) using drought indices and aridity values. Prog Phys Geogr 43(5):627-642. https://doi.org/10.1177/ 030913319860224

Ranero CR, von Huene R, Flueh E, Duarte M, Baca D, McIntosh K (2000) A cross section of the convergent Pacific margin of Nicaragua. Tectonics 19(2):335-357

Sánchez-Murillo R, Esquivel-Hernández G, Welsh K, Brooks ES, Boll J, Alfaro-Solís R, Valdés-González J (2013) Spatial and temporal variation of stable isotopes in precipitation across Costa Rica: an analysis of historic GNIP records. Open J Mod Hydrol 3(4):226-240. https://doi.org/10.4236/ojmh.2013.34027

Spinelli GA, Saffer DM, Underwood MB (2006) Hydrogeologic responses to three-dimensional temperature variability, Costa Rica subduction margin. J Geophys Res 111:B04403. https://doi.org/10. 1029/2004JB003436

Struss I, Brandes C, Blisniuk P, Winsemann J (2007) Eocene deep-water channel-levee deposits, Nicaragua: channel geometries and internal deformation patterns of six outcrops. In: Nilsen TH, shew RD, Steffens GS, Studlick JRJ (eds) Atlas of deep-water outcrops. AAPG studies in geology, 56, CD Rom, $31 \mathrm{pp}$

Struss I, Artiles V, Cramer B, Winesmann J (2008) The petroleum system in the Sandino forearc basin, offshore western Nicaragua. J Pet Geol 31:221-224

Tomaszewska B, Szczepański A (2014) Possibilities for the efficient utilisation of spent geothermal waters. Environ Sci Pollut Res 21: 11409-11417

Tortella BT, Tirado D (2011) Hotel water consumption at a seasonal mass tourist destination: the case of the island of Mallorca. J Environ Manag 92:2568-2579

Webster TC, Waite L, Markley B (2001) Water Resources Assessment of Nicaragua, US Army Corps of Engineers Mobile District and Topographic Engineering Center, Washington, DC, 122 pp

Winsemann J, Seyfried H (1991) Response of deep-water forearc systems to sea-level changes, tectonic activity and volcaniclastic input in 
Central America. In: MacDonald DIM (ed) Sea-level changes at active plate margins: processes and products. J Geol Soc IAS Spec Pub 1 12:217-240. https://www.bas.ac.uk/data/our-data/publication/ sea-level-changes-at-active-plate-margins-processes-and-products/. Accessed May 2021

Woods W (1994) An introduction to boron: history, sources, uses, and chemistry. Environ Health Perspect 102:5
World Health Organization (WHO) (2017) Guidelines for drinking-water quality, 4th edn, incorporating the first addendum. World Health Organization, Geneva. http://www.who.int/water_sanitation_ health/water-quality/guidelines/en/. Accessed May $20 \overline{2} 1$

Publisher's note Springer Nature remains neutral with regard to jurisdictional claims in published maps and institutional affiliations. 